REVISTA DE DERECHO UNED, NÚM. 11, 2012

\title{
ANTECEDENTES DEL ACTUAL DELITO DE CREACIÓN DE RIESGO PARA LA SALUD DEL TRABAJADOR
}

\section{PRECEDENTS OF THE CURRENT CRIME OF CREATION OF THE RISK FOR THE HEALTH OF THE WORKER}

Rosa Salvador Concepción

Abogada y Doctora en Derecho

Resumen: Nuestro vigente Código Penal, publicado por Ley Orgánica del 10/1995, de 22 de noviembre, recoge en su Libro II, de Los Delitos y sus Penas, en el Título XV, de Los Delitos contra los Derechos de los Trabajadores, un Título autónomo, que dejaba atrás su anterior inclusión dentro del Título dedicado a los Delitos contra el Patrimonio y contra el Orden Socioeconómico, persiguiéndose de esta forma, la consolidación de los derechos del trabajador en su vertiente más humana, y superándose así, la ancestral visión económica e instrumental de estos derechos.

Este Título cuenta con un total de ocho artículos -del 311 al 318entre los que se encuentran, los preceptos 316,317 y $318^{1}$ que se

${ }^{1}$ Artículo 316. "Los que con infracción de las normas de prevención de riesgos laborales y estando legalmente obligados, no faciliten los medios necesarios para que los trabajadores desempeñen su actividad con las medidas de seguridad e higiene adecuadas, de forma que pongan así en peligro grave su vida, salud o integridad física, serán castigados con las penas de prisión de seis meses a tres años y multa de seis a doce meses".

Artículo 317. "Cuando el delito a que se refiere el artículo anterior se cometa por imprudencia grave, será castigado con la pena inferior en grado».

Artículo 318. "Cuando los hechos previstos en los artículos de este título se atribuyeran a personas jurídicas, se impondrá la pena señalada a los administradores o encargados del servicio que hayan sido responsables de los mismos y a quienes, conociéndolos y pudiendo remediarlo, no hubieran adoptado medidas para ello. En estos supuestos la 
dedican a la penalización de la falta de medidas de prevención de riesgos laborales en la empresa, presentándose como delitos de peligro que castigan la creación de riesgo grave para la vida, salud e integridad física de los trabajadores. Así, el artículo 316 se dedica a la versión dolosa del delito, el 317 a la imprudente y el 318, a la especial autoría, en el caso de Personas Jurídicas.

El legislador de 1995, año de publicación del actual Código, articulaba de esta forma una especial protección para el trabajador, al adelantar la barrera punitiva antes incluso, de la creación del daño, formulando en estos artículos la intervención penal ya al originarse el peligro.

La idea no era novedosa, el orden penal ya se había ocupado de este injusto en anteriores Códigos si bien el resultado había sido ineficaz. En este artículo vamos a estudiar con perspectiva histórica los antecedentes de los citados artículos 316 a 318.

Palabras clave: Prevención de riesgos. Antecedente histórico. Peligro. Trabajador. Salud laboral.

Abstract: Our Penal Code published by Organic Law of 10/1995 of November 22, in the Title the XVth of The Crimes against the Laws of the Workers as an autonomous Title which was leaving behind his previous incorporation inside the Title dedicated to the Crimes against the Heritage and against the Socioeconomic Order, being chased of this form, the consolidation of the rights of the worker in his more human slope, and excelling itself this way, the ancient economic and instrumental vision of these rights. This Title possesses a total of eight articles -from 311 to 318- between those who are, the rules 316, 317 and 318 that devote themselves to the penalty of the lack of measures of prevention of labor risks in the company, appearing as crimes of danger that punish the creation of serious risk for the life, health and physical integrity of the workers. This way, the article 316 devotes itself to the fraudulent version of the crime, 317 to the imprudent one and 318, to the special authorship, in case of Legal persons.

The legislator of 1995, year of publication of the current Code, was articulating of this form a special protection for the worker, on having advanced the punitive barrier before even, of the creation of the hurt, formulating in these articles the penal intervention already on the danger having originated. The idea was not new, the

autoridad judicial podrá decretar, además, alguna o algunas de las medidas previstas en el artículo 129 de este Código». 
penal order already had dealt with unjust this one in previous Codes though the result had been ineffective. In this article we are going to study with historical perspective the precedents of the mentioned articles 316 to 318 .

Keywords: Prevention of risks. Historical precedent. Danger. Worker. Labor health.

Recepción original: 18 07/2012

Aceptación original: 20/07/2012

Sumario: I. Etapa predemocrática; II. Etapa democrática; II.1. Época actual.

\section{ETAPA PREDEMOCRÁTICA}

Para estudiar el tratamiento que ha tenido en los anteriores Códigos Penales la Responsabilidad Penal inherente a la falta de condiciones de seguridad e higiene en la empresa, empezaremos comentando de manera anecdótica que la primera alusión legislativa acerca de los riesgos laborales en la empresa surge en el ámbito civil, de forma antiquísima en los artículos 1902 y 1903 del Código Civil aprobado por Real Decreto de 24 de julio de $1889^{2}$. Muy alejada resulta esta regulación de la actual que nos ocupa ya que esta protección se centraba en las consecuencias de la acción del empleado sobre terceros pero descuidaba totalmente el daño que se podían causar ellos mismos aún en el correcto ejercicio de sus funciones. Este contenido pues, es propio de las antiguas tesis instrumentalistas que concebían al empleado como mera herramienta productiva y a la actividad empresarial, como una forma de crear riqueza nunca reinvertida en los trabajadores ni en sus condiciones salubres de trabajo. De manera, que la única preocupación de nuestro Código Civil era como vemos, articular la responsabilidad del empleador frente a terceros perjudicados por la acción u omisión de sus subordinados pero en ningún momento, la de éste frente a sus propios empleados.

${ }^{2}$ En los que se establece la responsabilidad de aquel que por acción u omisión causare a otro daño interviniendo culpa o negligencia -artículo 1902-.

Y el artículo siguiente -1903- en su párrafo 4 señala literalmente que tal obligación es exigible en la empresa "a los dueños o directores de un establecimiento o empresa respecto de los perjuicios causados por sus dependientes en el servicio de los ramos en que los tuvieran empleados o con ocasión de sus funciones» determinando que, «esta responsabilidad cesará cuando estas personas prueben que emplearon toda la diligencia de un buen padre de familia para prevenir el daño». 
Tras esta referencia civil más ilustrativa que analítica vamos a centrarnos ya en el orden penal. El filósofo alemán Jellinek de primeros de siglo ya nos instruyó al comentar que «de la historia de un pueblo no quedará otra cosa que su Código Penal del mismo modo que un paleontólogo puede reconstruir la estructura de un animal prehistórico a partir de un hueso». Con ésto, la primera referencia normativa que tratara la penalización de la falta de condiciones de seguridad en el trabajo la encontramos en el Código Penal de 1928, en su artículo 578, dentro del Libro $2 .^{\circ}$ de los Delitos y sus Penas, Título IX de Los Delitos contra la Seguridad Colectiva, Capítulo 1. ${ }^{\circ}$ de los Estragos y Delitos Afines y Sección Segunda de los Delitos Afines a los Estragos Imputables a Imprevisión, Imprudencia e Impericia, donde se castiga a los que «dirigieren la instalación o instalaren aparatos de seguridad utilizados para proteger la vida o la seguridad de los empleados en minas, trabajos subterráneos o en cualquier género de industrias peligrosas dando lugar por su imprevisión, imprudencia o impericia a un peligro para la salud o la vida de aquellos serán castigados con las penas de dos meses y un día a un año de prisión y multa de 1.000 a 50.000 pesetas» -en lo sucesivo, nos seguiremos refiriendo a las "pesetas» para respetar fielmente la redacción de la época-. Incurriendo en igual pena, según el párrafo segundo, «los encargados de la conservación y reparación de los mencionados aparatos así como los funcionarios encargados de su inspección» cuando por la misma causa, originaran igual peligro.

La expresa mención que hacen ambos artículos a la imprevisión, imprudencia e impericia nos hace remitirnos al Libro $1 .^{\circ}$ de la Infracción Criminal y su represión, Título 1. ${ }^{\circ}$ de la Infracción Criminal, Capítulo 1. ${ }^{\circ}$ de la Infracción Criminal en General, artículo 33 donde se regula que incurrirá asimismo en responsabilidad criminal el que con ocasión de acciones u omisiones no penadas por la ley, causare por imprevisión, imprudencia o impericia una lesión o daño que de ejecutarlo con intención, constituiría delito o falta mientras que, no incurrirá en la misma, el que ejecutando acciones lícitas con debida previsión, prudencia o pericia causare una lesión o daño por simple accidente material, sin culpa e intención de causarlo -artículo 35-. Y es ésta pues, la atención que el Código prestaba a la imprudencia dividiéndola en estos tres conceptos correspondientes actualmente con la culpa ya que en ese momento, la doctrina para aclarar su sentido, relacionaba la culpa procedente de la inteligencia para apreciar la imprevisión, la procedente de la voluntad para apreciar la imprudencia y la procedente de la sensibilidad para la impericia ${ }^{3}$. Aunque no dejó nunca de apreciarse una gran dificultad en su distinción al ser

\footnotetext{
${ }^{3}$ Jaramillo García, Novísimo Código Penal Comentado y Cotejado con el de 1870,
} 
estos tres términos, según se puede apreciar, de un alto contenido subjetivo que impedía diferenciarlos con total seguridad.

El primer precedente a la protección penal del trabajador lo encontramos pues en este artículo 578 cuyo campo de aplicación, era bien restringido al afectar entonces únicamente, a los trabajadores ocupados en minas, trabajos subterráneos o industrias peligrosas cuando fueran puestos en peligro, por la actuación imprudente de los que instalaran o dirigieran la instalación, de los equipos de seguridad utilizados por éstos. Ni siquiera se establece aquí, una protección total a la salud de los trabajadores ocupados en estos trabajos especialmente penosos sino sólo, en lo que respecta a los riesgos inherentes a una instalación incorrecta de los aparatos de seguridad castigando de igual modo el supuesto de una conservación, reparación o inspección incorrecta de estos aparatos -artículo 578.2- y eso sí, nunca extendiendo la protección penal a otras actividades peligrosas propias de estos empleos. Tal regulación, aunque se establece como un delito de peligro abstracto de amplia protección para el trabajador al requerir únicamente la puesta en peligro para la salud o la vida de éste, entendidas ambas en su sentido más extenso, olvidaba por otro lado de forma expresa la versión dolosa del delito, al incluirse tan solo su regulación en la Sección Segunda dedicada como hemos visto, a la imputabilidad por «imprevisión, imprudencia e impericia» como tres tipos de imprudencia que además incluso, acababa penando por igual, al no matizar si se trataba de imprudencia grave o leve, pudiéndose admitir entonces las dos.

Recordaremos que es en este momento histórico cuando Primo de Rivera gobierna el país desde 1923 y de su dictadura es fruto este Código del 1928 donde se establece la promulgación novedosa de diversas disposiciones penales y la modificación de las ya existentes para adaptarlas al nuevo estado autoritario mediante la Real Orden de 12 de marzo de 1926 con la que el General se dirigió a la Sección Penal de la Comisión Codificadora dándole las bases a partir de las cuales se habría de reformar el Código de 1870.

El resultado fue no ya un Proyecto de nueva edición del Código Penal de 1870 sino por todas sus innovaciones, un nuevo Código que sería aprobado por Real Decreto-Ley el 8 de septiembre de 1928. Este Código pretendía, y digo pretendía porque quedo sólo en éso, caracterizarse por la defensa social como criterio predominante con intención de no dejar sin sanción ningún delito culposo, motivo por

La Gaceta Regional, Salamanca, 1928, págs. 70 y ss. Castejón y Martínez de Arizala F., Tratado De Derecho Penal. Parte Especial, Ed. Reus, Madrid, 1931, pág. 70. 
el que se incorporaron con especial acento varios delitos imprudentes ${ }^{4}$. Pero muy lejos de esta pretensión, el espíritu del Código en lo que a nuestro estudio respecta, era más que la defensa social, la protección de la producción de las empresas, siendo el trabajador considerado como un mero instrumento de esa producción, con más deberes que derechos y que junto con los del propio empresario, conformaban los conocidos deberes laborales ${ }^{5}$. Las variaciones más importantes introducidas con respecto a su precedente Código estaban englobadas en los artículos 559 a 578 de los Delitos de Estragos y sus Afines de los que algunos preceptos se trajeron del Proyecto de la Ley de Explosivos de 10 de julio de 1894, otros se tomaron del Proyecto de 1912 y un último grupo, como es el artículo que nos ocupa, fueron creados por completo. El objetivo de esta nueva regulación de los Estragos y Afines, era la defensa de la colectividad contra los delitos voluntarios o contra aquellos imputables de forma imprudente ${ }^{6}$ por «imprevisión, imprudencia o impericia» realizados, según establece expresamente la Exposición de Motivos del texto, por la incipiente preocupación acerca del dominio cada vez mayor del ser humano sobre las fuerzas de la naturaleza en el acelerado progreso tecnológico que en ese momento histórico, acusaba el país. De ahí que en el artículo 578 se preste más atención a los supuestos de destrucción o interrupción del progreso técnico al tratarlos como una acción u omisión imprudente que conllevaría el deterioro directo de los aparatos de seguridad y con esto, la consecuente pérdida de la función protectora que éstos habrían de realizar. Se conformaba así como un delito de peligro ${ }^{7}$, según incluso la literalidad del precepto, que protegía a los trabajadores del riesgo inherente a los propios aparatos de seguridad, adelantando de esta forma la barrera punitiva con una clara intención de prevenir el daño, si bien, ésta podía ser interpretada como una de las primeras demostraciones que encontramos de una novedosa preocupación del legislador de la época por la salud del trabajador. Aún así, mayoritariamente la doctrina del

${ }^{4}$ Jaramillo García, M., Novísimo Código Penal Comentado y cotejado con el de $1870 \ldots$, cit., pág. 244.

${ }^{5}$ Arroyo Zapatero, L., La Protección Penal de la Seguridad en el Trabajo, Colección Jurídica. Servicio Social de Higiene y Seguridad en el Trabajo, Madrid, 1981, págs. 23 a 26.

${ }^{6}$ Cuello Calón, E., El Nuevo Código Penal Español, Ed. Bosch, Barcelona, 1929, pág. 249. Jiménez de Asúa, L. y Antón Oneca, J., Derecho Penal. Parte Especial, Ed. Reus, Madrid, 1930, pág. 192.

${ }^{7}$ Lascuraín Sánchez, J.A., La Protección Penal de la Seguridad e Higiene en el Trabajo, Ed. Civitas, Madrid, 1994, págs., 128 y 129. Fernández Marcos, L., La Seguridad e Higiene en el Trabajo ante la Reforma del Código Penal, En Revista de Política Social (R.P.S), n. ${ }^{\circ} 140,1983$, pág. 18. 
momento ${ }^{8}$ señaló que el bien jurídico protegido en el precepto era uno de carácter colectivo, la seguridad en el trabajo, sin apreciar la salud como último Bien individual objeto de tutela.

En una primera lectura de este precepto ya podemos intuir la principal crítica que le fue unánimemente achacada por la doctrina9: el campo de aplicación resultaba demasiado limitado a «minas, trabajos subterráneos o cualquier género de industrias peligrosas» dejando al trabajador desprotegido en el resto de las actividades laborales que indudablemente, también conllevaban su riesgo. Además se dirigía su protección tan solo en lo referente al manejo de aparatos de seguridad pudiendo ser su sujeto activo únicamente, el instalador, encargados de la conservación o reparación y los funcionarios técnicos o administrativos encargados de la inspección ${ }^{10}$ de estos aparatos que además resultaban ser, sólo una parte como sabemos, de las medidas de seguridad de carácter material ${ }^{11}$. De manera que en ningún momento señalaba ni siquiera al empresario ${ }^{12}$ como posible autor, en una clara contradicción con el artículo 266 del entonces vigente Código de Trabajo de 1926 que obligaba a este empresario a velar por la seguridad de los trabajadores. Y además, no atendía a la forma omisiva de no instalar aparatos de seguridad, dejando sin protección esta carencia tan frecuente en las empresas ${ }^{13}$.

De cualquier forma, cuando llegado el 14 de abril de 1931 Alcalá Zamora, Presidente del Gobierno Provisional, anuncia la II República y con ésto, el Código de 1928 es derogado por Decreto de 15 de abril de 1931 y de nuevo se declara en vigor el Código de 1870, con lo que volvemos a quedarnos sin remisión expresa alguna a los delitos contra los trabajadores por falta de condiciones de seguridad en la empresa. De forma que este delito de peligro del artículo 578 desaparece primero con la derogación del Código de 1928 y después con la Reforma del Código Penal de 5 de noviembre de 1932 que aprobaba el Código de 1932, derogando de nuevo el de 1870 pero manteniendo, su estructura y espíritu conservador, y que en lo que

${ }^{8}$ Fernández Marcos, L., La Seguridad e Higiene en el Trabajo..., cit., pág. 18. Jiménez de Asúa, L. y Antón Oncea, J., Derecho Penal..., cit., Pág. 187.

${ }^{9}$ Fernández Marcos, L., La Seguridad e Higiene en el Trabajo..., cit., pág. 18.

${ }^{10}$ Arroyo Zapatero, L., La Protección Penal de la Seguridad En El Trabajo..., cit., pág. 244. Fernández Marcos, L., La Seguridad E Higiene En El Trabajo..., cit., pág. 18

${ }^{11}$ Castellón y Martínez de Arizala, F., Tratado de Derecho Penal. Parte Especial..., cit., pág. 376.

${ }^{12}$ Lluis y Navas, J. Derecho De La Seguridad e Higiene en el Trabajo. Ed. Cedecs, Barcelona, 1996, pág. 49.

${ }^{13}$ Arroyo Zapatero, L., La Protección Penal de la Seguridad en el Trabajo..., cit., pág. 253. 
a nuestro estudio respecta, volvía a dejar sin protección alguna a los trabajadores perjudicados con ocasión de la realización de su trabajo en ausencia de las correctas medidas protectoras.

Para la siguiente referencia normativa habrá que esperar pues, al artículo 423 del Código Penal de 1944 en su Capítulo IV referido a las "Lesiones», del Título VIII de los "Delitos contra las Personas", del Libro Segundo de los «Delitos y sus Penas». Cuando en enero de 1938 el General Franco pasa a convertirse en Jefe de Estado y en agosto del 1939 es suprimida la necesidad de deliberación previa del Consejo de Ministros para que el Jefe de Estado pueda dictar Leyes o Decretos con lo que hasta la promulgación del nuevo Código Penal siguió vigente el Código Penal de 1932 pero el Gobierno franquista fue dictando una serie de Leyes Penales Especiales para trasladar sus concepciones a la dictadura ahora vigente y para privar expresamente de eficacia aquellas resoluciones que fueran contrarias a su estructura.

De esta forma, la Ley de 19 de julio de 1944 autorizó al gobierno para publicar un nuevo texto refundido del Código Penal aunque obviamente, la producción legislativa habría de ser sumisa al nuevo régimen. El resultado fue un Código de gran dureza y orientado a proteger la permanencia de un Estado de ideas políticas, religiosas y sociales de marcado espíritu conservador. El Código Penal-Texto Refundido de 1944 incluía escasas modificaciones con respecto al Código de 1932 pero sí destaca para nuestro interés, la incorporación del artículo 423: "Cualquiera de las penas señaladas en los tres artículos anteriores»-referentes éstos a las lesiones- serían, «aplicables a los que por infracciones reiteradas y probadamente dolosas de las leyes del trabajo ocasionen quebranto grave en la salud de los obreros y en la producción en general».

El artículo insertaba de esta forma, de manera expresa, la sanción perteneciente a la infracción de las Leyes de Trabajo que ocasionaran quebranto grave a la salud de los obreros, olvidándose de que las principales normas preventivas de la época tenían forma de Reglamento ${ }^{14}$ y obligando con ésto a los Tribunales a entender esta alusión, en un sentido material y no formal, para favorecer así la aplicabilidad del precepto.

La determinación expresa a la producción nacional como objeto de tutela hizo que la mayoría de la doctrina ${ }^{15}$ entendiera que era esta

${ }^{14}$ Rodríguez Muñoz, J.A., Derecho Penal. Parte Especial, Ed. Gráfica Administrativa, Madrid, 1949, pág. 257.

${ }^{15}$ Arroyo Zapatero, L., La Protección Penal..., cit. págs. 229 y ss. 
productividad y no la salud de los trabajadores, el verdadero Bien Jurídico protegido, al interpretar que la buena salud del obrero era considerada como una herramienta idónea para la consecución del que realmente era el principal objetivo, el rendimiento económico empresarial y con ésto, nacional.

La barrera punitiva volvía a atrasarse con este artículo y en comparación con su precedente ya que se penaba la lesión ${ }^{16}$ y no la puesta en peligro exigiéndose además dolo sin atender a la forma imprudente ${ }^{17}$.Mientras, su última expresión «salud de los obreros y en la producción general» posicionaba en el mismo nivel de protección la salud de los trabajadores que el rendimiento económico, con lo que se podía intuir que se concebía la salud de los obreros como más bien, un instrumento para alcanzar aquella producción ${ }^{18}$.La alusión abierta al posible sujeto activo del delito, "Los que por infracciones reiteradas y probablemente dolosas de las Leyes del Trabajo...», definía el precepto como una norma penal en blanco y dejaba que la doctrina mayoritaria llegara a establecer como posibles autores a cualquier persona que infringiera estas leyes, decantándose hacia la consideración de la existencia de un delito común ${ }^{19}$. Además este artículo 423 obtuvo una dura crítica por la imprecisión efectuada en

${ }^{16}$ Las penas a las que hacía referencia eran las correspondientes a los reos de lesiones graves sobre los que caía la pena de: en el párrafo $1 .^{\circ}$, prisión mayor -de seis años y un día a doce años- si de resultas de las lesiones quedare el ofendido imbécil, impotente o ciego; en el párrafo $2{ }^{\circ}$ prisión menor -de seis meses y un día a seis años- más multa de 5.000 a 10.000 de las antigüas pesetas, si de las lesiones el ofendido hubiere perdido un ojo o, algún miembro principal o, hubiere quedado impedido de él o inutilizado para el trabajo a que hasta entonces se hubiere dedicado; según el párrafo $3 .^{\circ}$, prisión menor también si en este caso, el ofendido hubiere quedado deforme o, perdido un miembro principal o quedado inutilizado de él o, hubiere estado incapacitado para su trabajo habitual o, enfermo por más de noventa días y; según el párrafo $4 .^{\circ}$, con la de arresto mayor -de un mes y un día a seis meses-y multa de 1.000 a 5.000 pesetas, si las lesiones hubiesen producido al ofendido enfermedad o incapacidad para el trabajo por más de treinta días. Si por último, las lesiones no comprendidas anteriormente producían al ofendido incapacidad para el trabajo por más de quince días, o necesidad de asistencia facultativa por igual tiempo, se reputaban menos graves y eran penadas con arresto mayor, destierro y multa de 1.000 a 5.000 pesetas, según el prudente arbitrio de los Tribunales -artícu$\operatorname{los} 420$ y $422-$.

${ }^{17}$ Quintano Ripollés, A., Tratado de la Parte Especial de Derecho Penal. T. IV-Vol.I, Ed. Revista de Derecho Privado, Madrid, 1972, pág. 731. Ferrer Sama, A., Comentarios al Código Penal, Ed. Estades, Madrid, 1956, pág. 361.

${ }_{18}$ Arroyo Zapatero, L., La Protección Penal de la Seguridad en el Trabajo..., cit., págs. 229 y 230.

${ }_{19}$ Arroyo Zapatero, L. Manual de Derecho Penal del Trabajo, Ed. Praxis, Madrid, 1988, págs. 150 y ss. Diego Díaz Santos, R., Las Lesiones Laborales del Artículo 427 Del Código Penal, en Cuadernos de Política Criminal, núm. 2, 1977, pág. 42. 
el mismo al valorar la reiteración de la infracción, sin indicar expresamente cuándo se podía entender una acción u omisión «reiterada», de tal manera que la doctrina ${ }^{20}$ se pronunció hacia interpretar que tendrían que concurrir más de una infracción para que el juzgador dedujera la existencia de una situación lo suficientemente grave como para justificar la intervención penal. También se criticó por la exigencia que contenía de castigar sólo las conductas u omisiones dolosas ${ }^{21}$, porque muy difícilmente conseguían probarse, por lo que también sufrió además del olvido de la doctrina, la inaplicación por parte de los Tribunales en cuarenta y tres años de su vigencia formal $^{22}$, lo que provocó que con ocasión del Proyecto de Revisión Parcial del Código Penal y otras Leyes Penales en 1961 se indujera al Gobierno a proponer la supresión del artículo.

Así, las Cortes decidieron mantener el precepto ${ }^{23}$ si bien con una nueva formulación que sirviese a los fines pretendidos dando al artículo una nueva redacción ${ }^{24}$ en la que se sancionaba a los que "por infracciones graves de las leyes de trabajo ocasionaren quebranto apreciable a la salud de los obreros». De nuevo se utilizaba la misma fórmula amplia para señalar al posible sujeto activo que ya utilizara el artículo 423 - «los que por infracciones graves de las leyes de trabajo»-, pero en cambio por la literalidad del precepto se podía afirmar que por fin, el Bien tutelado era ya la salud personal del trabajador, como así interpretó un amplio sector doctrinal ${ }^{25}$. Mientras, una corriente más minoritaria, dedujo la existencia de dos Bienes Jurídicos, uno la salud en su dimensión microsocial, y otro, la seguridad en el trabajo de carácter macrosocial ${ }^{26}$. De cualquier forma, era la primera vez que en una interpretación teleológica e incluso literal del Bien tutelado se apuntaba a la salud personal como objeto de tutela de lo que se deducía, una

${ }^{20}$ Cuello Calón, E., Derecho Penal. Parte Especial..., cit., pág. 578.

${ }^{21}$ Baylos Grau, A. y Terradillos Basoco, J., Derecho Penal del Trabajo, Ed. Trotta, Madrid, 1997, págs. 116 y 117. Lascuraín Sánchez, J.A., La Protección Penal de...., cit., págs. 386 y 387. Terradillos Basoco, J., Delitos contra los Derechos de los Trabajadores II: Art. 314, 315, 316 y 317 del Código penal, en Empresa y Derecho Penal, Ed. Tirant lo Blanch, Valencia, 2002, pág. 317.

${ }^{22}$ Arroyo Zapatero, L., Comentarios A la Legislación Penal. La Reforma Penal de 1983, Ed. Edersa, 1985, Madrid, pág. 919-932.

${ }^{23}$ Quintero Olivares, G., Algunas Consideraciones Críticas sobre los Delitos contra la Libertad y Seguridad en el Trabajo en la Reforma del Código Penal de 15 de noviembre de 1971, Revista Jurídica de Cataluña, Núm. 80, pág. 312.

${ }^{24}$ Muñoz Conde, F., Derecho Penal. Parte Especial, Ed. Tirant lo Blanch, Valencia, 2007, pág. 343.

${ }_{25}$ Arroyo Zapatero, L., Manual de Derecho Penal del Trabajo..., cit., págs. 150 y ss.

${ }^{26}$ Bustos Ramírez, J., Manual de Derecho Penal. Parte Especial. Ed. Ariel. Barcelona, 1991, pág. 67. 
incipiente humanización del concepto de seguridad en el trabajo. El nuevo artículo sería el 427, formulado dentro del Capítulo de Lesiones contra las Personas tras la Reforma promovida por la Ley de 23 de diciembre de 1961 por la que vio la luz el Código Penal- Texto Revisado de 1963, disponía que «las penas señaladas en los artículos 420 a 422 en sus respectivos casos serían aplicables a los que por infracciones graves de las leyes de trabajo ocasionaran quebranto apreciable a la salud o integridad corporal de los obreros», tan sólo modificando lo referente a las multas donde se aumentaba a 50.000 pesetas, la multa considerada en el artículo 420.2 y subía a entre 5.000 a 25.000 pesetas la establecida en el artículo 420.4 y 422.

El artículo 427 sustituía entonces al ya antiguo 423 pero suponía también un radical incumplimiento de la voluntad de las Cortes expresada en esta Ley de Bases para la modificación del Código, pues al apreciar expresamente que ocasionaren y omitiendo el que «o puedan ocasionar», el precepto se mantenía igual que el 423 como mero delito de lesión dejando descubierta la eficacia político criminal propia, de un delito de puesta en peligro. Por este motivo autores como Quintano Ripollés ${ }^{27}$ opinaban que el artículo 427 se limitaba a corregir los más burdos defectos del artículo 423 al convertirse en un auténtico delito contra las personas pero que caía de nuevo, en el mismo error de convertir lo culposo en doloso. Además, estaba lleno de términos imprecisos tales como: «infracciones graves», "leyes de trabajo» o «quebranto apreciable», de manera que la doctrina más mayoritaria se pronunció de la misma manera ${ }^{28}$, interpretando el 427 como un tipo impreciso que además, castigaba como dolosas las conductas tanto doloso eventuales como imprudentes criticándose en consecuencia el precepto como una grave violación de los Principios Fundamentales de Culpabilidad y Proporcionalidad de la Pena. Jove Jane/ Moráles Prats llegan incluso a calificar el artículo de disfuncional ${ }^{29}$ y Antón Oneca $^{30}$ afirma que en el artículo 427 las lesiones culposas tendrían las mismas penas que las dolosas y en desproporción con las castigadas conforme al artículo 565 que se refería a la Imprudencia Punible y que resultaba además, la vía normalmente utilizada por los Tribunales ${ }^{31}$

${ }^{27}$ Tratado de la Parte Especial del Derecho Penal..., cit., pág. 100.

${ }^{28}$ Quintano Ripollés, A., Tratado de la Parte Especial del Derecho Penal..., cit., pág. 101.

${ }^{29}$ La Protección Penal del Trabajo ante el Debate Legislativo, Revista Técnico Laboral, núm. 6, 1980, pág. 2.

${ }^{30}$ Notas Críticas Al Código Penal, en Estudios Penales: Libro Homenaje Al P. J. Antón Oneca, Ed. Universidad de Salamanca, Salamanca, 1982, pág. 786.

${ }^{31}$ Quintero Olivares, G., Algunas consideraciones críticas..., cit., pág. 312. 
para hacer efectiva la protección penal de la Seguridad e Higiene en su forma imprudente ${ }^{32}$.

El artículo 565 resultó aplicable así, a todo hecho o resultado lesivo no deliberadamente querido por el sujeto activo del delito y en este sentido, no solamente se aplicaba en materia de muerte o lesiones por accidente o enfermedad del trabajo sino también, en otros campos alejados del mundo laboral especialmente, en el de los accidentes de tráfico, de los que se derivaban muerte o lesiones. A su amparo, la muerte o lesiones por accidente de trabajo se calificaban como homicidio o lesiones por imprudencia si bien, el delito era de los llamados de resultado, de forma que la mera conducta manifiestamente peligrosa e infractora de las normas de seguridad e higiene en el trabajo, por mucha gravedad e intensidad que pudiera revestir esa creación de riesgo, carecía de reproche penal. La relevancia penal surgía pues, cuando la acción u omisión infractora y antijurídica se concretaba en una efectiva lesión del bien jurídico protegido y el delito de homicidio o lesiones por imprudencia requería además, la concurrencia de dos elementos básicos: el psicológico, consistente en prever el sujeto un resultado evitable, y el normativo acreditado éste por la violación de un deber objetivo de cuidado; elementos ambos comunes a las distintas modalidades de imprudencia.

Autores como Muñoz Conde ${ }^{33}$, analizando la relación entre el 565 con el 427, manifestaron que se trataba de una penalización de infracciones graves de las normas de seguridad en el trabajo y que en realidad, no era necesaria su mención expresa pues, la mayoría de las veces eran conductas imprudentes para cuyo castigo, bastaba el tipo abierto del 565. Los Tribunales por su parte, olvidaron la existencia del artículo 427, con igual rotundidad que lo hicieron con el viejo 423. Sólo una Sentencia del Tribunal Supremo nos es conocida pero tanto porque no entra en el fondo del asunto como por los re-

${ }^{32}$ Ya que formulaba que, «el que por imprudencia temeraria ejecutare el hecho que si mediare malicia constituiría delito, será castigado con la pena de prisión menor (párrafo 1. ${ }^{\circ}$ ); el que por infracción de reglamentos cometiera un delito por simple imprudencia o negligencia, se le impondrá la pena de arresto mayor y (párrafo $2 .^{\circ}$ ); cuando se produjera muerte o lesiones graves a consecuencia de imprudencia o negligencia profesional se impondrán en su grado máximo las penas señaladas en este artículo y dichas penas se podrán elevar en uno o dos grados a juicio del Tribunal (párrafo 5. ${ }^{\circ}$ ) las infracciones penadas en este artículo cometidas con vehículos de motor, llevarán aparejada la privación del permiso de conducción por tiempo de tres meses y un día a diez años (párrafo 6. ${ }^{\circ}$ ) no pudiendo penarse con penas que resultaren igual o superiores a las que corresponderían al mismo delito contenido intencionalmente (párrafo $7 .^{\circ}$ )» -artículo 565.

${ }^{33}$ Derecho Penal. Parte Especial, Ed. Tirant lo Blanch, Valencia, 2007, pág.93. 
sultados de punición a que en ella se llegan, no puede considerarse más que como un, ya calificado por la doctrina, lapsus del Tribunal de Instancia y del propio Tribunal Supremo ${ }^{34}$. La Sentencia a la que nos referimos es la de 13 de mayo de $1969^{35}$ que se limita a considerar aplicable el artículo 427 tras constatar que las infracciones de leyes de trabajo fueron graves y el quebranto de la salud de los obreros apreciable, sin hacer referencia alguna al elemento subjetivo doloso o imprudente que verdaderamente, era lo que suponía la cuestión más controvertida.

Ilustrativa resulta al respecto, la Memoria del Fiscal del Tribunal Supremo de 15 de septiembre de 1972 que como así lo hiciera la de 1968, justificaba la falta de aplicación del precepto por la errónea equiparación de la culpa con el dolo, reiterando así la ya conocida crítica que la doctrina científica efectuaba a este artículo 427 y que apreciaba que su contenido violaba el Principio de Culpabilidad.

El legislador de 1963 sólo podía entonces pretender una cosa, la ampliación del ámbito de aplicación del artículo 423 o sea, que las penas de las lesiones dolosas pudieran aplicarse necesariamente a todas las conductas causadas por infracción de las leyes laborales tanto, si el tipo era doloso eventual como si era meramente imprudente, y ya fuera la imprudencia temeraria, como simplemente antirreglamentaria.

El artículo 427 se reservaba así a las lesiones por infracciones reiteradas, dolosas o no, excluyendo la aplicación del 565 que hasta entonces, entraba en juego siempre que las infracciones no fueran dolosas o reiteradas. Con lo que en definitiva, se agravó aún más el defecto del 423 aunque la intención fuera la de poner de acuerdo este precepto con ese Principio de Culpabilidad al suprimir la errónea presunción de dolo eventual. El resultado como vemos, estuvo lejos de esta intención inicial.

La interpretación que encuentro más acertada y la que secundo es la que realiza Arroyo Zapatero ${ }^{36}$ cuando analiza que el tipo del 427

${ }^{34}$ Fernández Marcos, L., La Seguridad e Higiene en el Trabajo..., cit., pág. 7.

${ }^{35}$ El Considerando Primero de la Sentencia (Sentencia del Tribunal Supremo de 13 de mayo de 1969 -JUR 2821), relaciona la infracción del autor con el Reglamento de Seguridad del Trabajo, en aquel momento vigente limitándose a reconocer la importancia de la infracción, en la realización en concreto de una zanja que prescindía, "de las entibaciones y revestimientos, cosa importante agravada por el extremo de estar trabajando a unos 30 metros de distancia, un rodillo vibratorio para compactar», pero, sin analizar el elemento subjetivo de la conducta del autor.

${ }^{36}$ Manual de Derecho del Trabajo..., cit., pág.141. 
era una conducta dolosa y en consecuencia, para que se realizara el tipo era necesario que el dolo del autor cubriera los elementos del tipo subjetivo y los elementos del tipo objetivo, es decir que el agente causara dolosamente la lesión por una dolosa infracción de las Leyes y Reglamento de Seguridad e Higiene del Trabajo. Si el dolo del autor no abarcaba ambos elementos, el precepto que habría de aplicarse era el que se formaba con la conjunción del tipo objetivo del 427 y el tipo subjetivo de la imprudencia contenida en la fórmula genérica del 565. En resumidas cuentas, un delito doloso de lesiones laborales, el del 427 y un delito imprudente de lesiones laborales, el del 427 en relación con el 565 que entraría entonces en juego cuando el autor no infringía dolosamente las leyes laborales o cuando infringiéndolas, no se daban los presupuestos del dolo eventual respecto del resultado lesivo. El delito doloso del artículo 427 sólo se realizaba pues, cuando se cubriera con dolo o con dolo eventual la producción del resultado ya que en nuestro derecho el dolo eventual era una forma de dolo punible como tal y no como imprudencia temeraria.

De cualquier manera, pese a los esfuerzos de la doctrina de la época por aclarar su contenido, la eficacia del artículo 427, como ya lo fuera la del artículo 423, fue nula.

Por orden cronológico llegamos entonces a la Ley 44/71 de 15 de noviembre que crea el artículo 499 bis dentro del Título XII de los Delitos contra la Libertad y Seguridad, del Libro II de los Delitos y sus Penas, Capítulo VIII bajo la rúbrica De los Delitos Contra la Libertad y Seguridad en el Trabajo para introducir el llamado Delito Laboral, integrado sólo por un artículo que respondía a lo ya formulado en su Exposición de Motivos, donde se manifestaba con sobrado interés la necesidad de acomodar nuestras leyes penales a lo convenido en Tratados internacionales suscritos por España, y a la realidad social de aquel momento.

Se trataría pues de una reforma parcial del entonces vigente Código Penal, provocada por el Decreto-Ley de 15 de febrero de 1952, y que aconsejaba la incorporación al Código Penal de este artículo. Este Decreto-Ley, acerca del Contrato de Trabajo, Montepíos y $\mathrm{Mu}$ tualidades de Previsión, establecía así en su párrafo cuarto la necesidad de velar por el cumplimiento de las disposiciones que regularan y ampararan las relaciones laborales, no sólo con la actuación de los organismos laborales sino también, con la aplicación de las sanciones penales pertinentes para quienes actuaran de forma dolosa.

En su artículo 1, determinaba que las empresas, bien personas jurídicas o físicas, que cedieran temporalmente todo o parte de su 
personal a otros empresarios, y tanto si lo efectuaban mediante el percibo de una compensación económica, o aún cuando fuese a título gratuito de servicios benévolos o de buena vecindad, estarían obligadas a cumplir rigurosamente con respecto a sus trabajadores, de todas las disposiciones legalmente impuestas en el orden laboral y en la esfera de la previsión social, abonándoles las retribuciones aplicables según las actividades a las que se dedicaran y a la función efectivamente desempeñada por estos empleados en cada instante.

En el supuesto además, de que dichas Empresas incumplieran los mencionados deberes, los empresarios que utilizarían personal cedido por aquellas, responderían solidariamente de las obligaciones sociales exigibles conforme a la legislación laboral, sin que pudiera alegarse en contrario la existencia de pacto. En su artículo 2.2 además se determinaba que si de los hechos cometidos se desprendiera la existencia de maquinaciones o confabulaciones dolosas, la Delegación de Trabajo correspondiente pasaría oportuno tanto de culpa a la jurisdicción penal ordinaria que podría imponer tanto a la empresa cedente como a la cesionaria las penas señaladas en el artículo 534 del Código Penal Vigente -arresto mayor y multa de 10.000 a 100.000 pesetas-.

Pues bien, tras este precedente sobreprotector que orientaba las regulaciones futuras a una mayor atención y cuidado a los trabajadores, se hacía necesaria la aparición del mencionado artículo 499 bis $^{37}$. La Ley de 15 de noviembre de 1971 que dio origen al precepto fue fruto directo de lo instado por el Consejo Nacional de Trabajado-

37 «Será castigado con pena de arresto mayor -de un mes y un día a seis meses- $y$ multa de 100.000 a 200.0000 de pesetas: $10^{\circ}$ el que usando de maquinaciones o procedimientos maliciosos imponga a los trabajadores a su servicio condiciones laborales o de seguridad social que perjudiquen los derechos que tengan reconocidos por disposiciones legales o convenios colectivos sindicales; 2. ${ }^{\circ}$ el que por cesión de mano de obra, simulación de contrato, sustitución o falseamiento de empresa o cualquier otra forma maliciosa suprima o restrinja los beneficios de la estabilidad en el empleo y demás condiciones de trabajo reconocidas a los trabajadores por disposiciones legales; $3^{\circ}$ el que trafique de cualquier manera ilegal con la mano de obra o intervenga en migraciones laborales fraudulentas aunque de ello se derive perjuicio para el trabajador.

El que en caso de crisis de una empresa hiciere ineficaces maliciosamente los derechos de los trabajadores incurrirá en las penas previstas en el artículo 519 de este Código -Prisión Menor- de seis meses y un día a seis años, si fuere comerciante, matriculado o no y con arresto mayor si no lo fuere.

Cuando los hechos previstos en los números anteriores fueren realizados por personas jurídicas se impondrá la pena señalada a los administradores o encargados del servicio que lo hubieran cometido o que, conociéndolos y pudiendo hacerlo, no hubieren adoptado medidas para remediarlos. En su caso procederá la responsabilidad civil subsidiaria de la empresa.» 
res en la Declaración de 4 de noviembre de 1970 donde se reiteraba la necesidad de tipificación de determinados comportamientos referidos a materias de: viviendas protegidas, seguridad social, gestión económica y de crédito y otras figuras específicas en materia social, abusos de las empresas en las relaciones laborales crisis fraudulentas de trabajo $y$ «trasgresión de las normas de higiene y seguridad en el trabajo susceptibles de originar accidentes y conductas antisociales gravemente lesivas para la dignidad y derechos de los trabajadores o la normalidad laboral en general».

El régimen sancionador que imponía este artículo era de naturaleza privativa y pecuniaria pero la pena de arresto mayor era insuficiente, así como la pecuniaria, al estar limitada por debajo de las 100.000 pesetas. La Comisión razonó esta restricción argumentando que «la multa era la pena pecuniaria que iba unida a una pena de privación de libertad y que las multas administrativas eran superiores a las que aplicaba el Código Penal porque tenían una función distinta».

Y es que este artículo 499 bis suponía para el Consejo no la meta definitiva pero sí un paso importante en sus aspiraciones, aunque en el estudio de la limitada eficacia que tuvo será inevitable que tengamos en cuenta el contexto político de España en aquel momento, con un régimen dictatorial y con una normativa fuertemente intervencionista que aún prohibía el ejercicio de derechos del trabajador tales como el de libre sindicación y el de huelga ${ }^{38}$.

En aquel momento, era obvia la necesidad social de empezar a considerar el trabajo no como mera mercancía sujeta a la voluntad de los patrones sino con el reconocimiento y la protección de la dignidad de los empleados. Se hacía necesario apreciar en definitiva, un Título Especial para este tipo de delitos. Este precepto 499 bis introducido por la reforma de 1971 e integrado en el Capítulo VIII de los Delitos contra la Libertad y Seguridad en el Trabajo, reflejaba así el llamado Delito Social aunque incluía cuatro figuras diferentes todas encaminadas a tutelar las mejores condiciones laborales de los trabajadores- De manera que podemos entender, que directamente relacionados con la seguridad e higiene en el trabajo son tan solo las dos primeras figuras, recogidas en los dos primeros párrafos. Para empezar, el 499 bis.1. ${ }^{\circ}$, plasma la figura de la «imposición de condiciones ilegales de trabajo y seguridad social» centrando así primero, la conducta punible en el verbo rector «imponer» esto es, someter a los trabajadores como sujetos pasivos a unas condiciones de trabajo o

${ }^{38}$ Rojo Torrecilla, E., Delitos Contra los Derechos de los Trabajadores, y Contra la Seguridad Social, Ed. Bosch, Barcelona, 1998, pág. 33. 
de seguridad social entendidas éstas, en sentido amplio ya que para su concreción, teníamos que acudir a los dispuesto en otras «disposiciones legales o convenios colectivos sindicales» que para terminar de integrar el injusto típico, habrían de ser perjudiciales para sus derechos o sea, limitativas o negadoras de tales derechos laborales y de seguridad social. Lo anterior quiere decir que se trata aquí de un delito de resultado que exige para su consumación la imposición o establecimiento de aquellas condiciones desfavorables, momento en que se perfecciona el delito. La protección de la seguridad e higiene en el trabajo la encontraríamos en este primer párrafo y así lo entendió la doctrina científica, integrándola en el término «condiciones de trabajo reconocidas en las disposiciones legales». Ahora bien, la propia naturaleza fraudulenta de este delito al reiterar el artículo la necesidad de «maquinaciones o procedimiento maliciosos», hacía que éste fuera necesariamente doloso excluyéndose en consecuencia, la posibilidad de su ejecución por culpa o imprudencia, cosa que perjudicó que se aplicara suficientemente por los Tribunales.

El segundo subtipo descrito en el 499 bis.2. ${ }^{\circ}$ y digo subtipo por determinar un campo de aplicación más restringido que el que de forma genérica era descrito en el párrafo primero, se realizaba ahora especialmente con ocasión de «cesión de mano de obra, simulación de contrato, sustitución o falseamiento de empresa». Estableciendo también la exigencia de un resultado centrado en la «supresión o restricción de los beneficios de la estabilidad del empleo u otras condiciones de trabajo» donde podemos de nuevo entender, integradas las condiciones de trabajo referentes a seguridad e higiene en la expresión, «reconocidas a los trabajadores por las disposiciones legales». Cabría interpretar que también exige para su perfección la «supresión o restricción de derechos» equiparable a la anterior «imposición de condiciones que perjudiquen...», así como volvía a presentarse como un precepto en blanco con necesidad de ser completado por las «disposiciones legales» de nuevo aquí aludidas. En este tipo además, tampoco cabía la versión culposa ya que volvía a reiterar que tales mecanismos habrían de producirse con carácter malicioso de forma abstracta aludido con la expresión «cualquier otra forma maliciosa», por lo que se hacía imprescindible el dolo.

En cambio, el art. 499 bis. $3 .^{\circ}$ tipificaba la figura denominada tráfico ilegal de mano de obra caracterizándose por la vulneración de la normativa que regula la llamada «cesión de mano de obra y la emigración para trabajar en el exterior»; de nuevo un precepto en blanco que nos remitía en este caso, a la Ley de Emigración para darle contenido. 
Y por último, la modalidad del párrafo $3 .^{\circ} 2$ consistía «en hacer maliciosamente ineficaces en caso de crisis de la empresa los derechos de los trabajadores» entendidos éstos una vez más de forma genérica y donde interpretamos otra vez, que podríamos incluir los referentes a la seguridad e higiene en el trabajo. Vuelve a su vez este subtipo a requerir el dolo y vuelve a precisar de la normativa laboral vigente para darle contenido, remitiéndose además para su castigo, a la pena establecida para el alzamiento de bienes -artículo 519-, lo que inevitablemente complicó aún más si cabe, su aplicación, ya que ello provocaba que la mayor parte de la jurisprudencia y la doctrina científica, lo interpretara como una modalidad de alzamiento de bienes requiriendo que se dieran entonces, todos y cada uno de los requisitos de tal delito para su consideración.

La responsabilidad penal de las personas jurídicas por su parte, vendría resuelta por el último párrafo al formular que cuando los hechos previstos en los números anteriores fueran realizados por personas jurídicas «se impondrá la pena señalada a los administradores o encargados del servicio que los hubieren cometido o que conociéndolos y pudiendo hacerlo no hubieren adoptado medidas para remediarlo". Esta indicación, «los administradores o encargados del servicio», era imprecisa lo que fue buscado a propósito por la Comisión de Justicia de las Cortes donde se optó por esta formula abierta al entenderse que era mejor dejar a los Tribunales la determinación de los posibles responsables según la estructura y organización funcional de cada empresa, al ser ésta de difícil apreciación de forma estándar. Pese a esta justificación esta imprecisión fue una decisión errónea, ya que sembró de dudas la interpretación y aplicación del precepto.

De manera, que encuadrar el artículo 499 bis en el Título XII del Código Penal y la denominación realizada al Capítulo VIII De los Delitos contra la Libertad y Seguridad en el Trabajo que lo contenía obligó a que se exigiera que la conducta entrañara un atentado a la libertad o a la seguridad en el trabajo ${ }^{39}$. El atentado a la libertad lo interpretaremos como sometimiento a la voluntad del trabajador ${ }^{40}$ en relación con su situación profesional obligándole a aceptar, ya por la acción u omisión del autor, unas condiciones laborales o de seguridad social que perjudicaban los derechos que tuviera reconocidos por disposiciones legales o convenios colectivos sindicales. El sometimiento de la voluntad del trabajador como contenido signi-

\footnotetext{
${ }^{39}$ Sainz Cantero, J. A., En torno a los delitos contra la libertad y seguridad en el trabajo. Ed. Estudios Sociales, Murcia, 1972, pág. 10.

${ }^{40}$ García Albero, R., Non bis in idem, material y concurso de Leyes Penales, Ed. Cedecs, Barcelona, 1995, págs. 57 y 58.
} 
ficativo del verbo «imponer», se podría consumar así en una acción u omisión dispuesta por el empresario u otras personas cuya condición ostentaran, en perjuicio de los derechos de los trabajadores, por lo que cabrían a su vez, las formas imperfectas de realización según aclaró expresamente entre otras, la Sentencia del Tribunal Supremo de 14 de marzo de $1985^{41}$.

El doblegamiento de la voluntad del trabajador, habría de conseguirse necesariamente además, por maquinaciones o procedimientos maliciosos ${ }^{42}$ determinación ésta, en la que entrarían las amenazas, intimidación u ofrecimiento de dádivas o promesas. Esa intención dañina, conformaba indudablemente el dolo de forma que dejaba fuera del tipo aquí reconocido cualquier actuación que se entendiera de naturaleza imprudente. Y ésta fue una de sus principales críticas que constantemente le fueron achacadas, la exigencia del dolo para su punición así como, la presentación del precepto como una norma penal en blanco que requería de la consulta constante a la normativa laboral de referencia para concretar el injusto penal.

Por su parte, cuando en la denominación del Capítulo se hacía mención expresa a la "seguridad» aclaremos que aquí, no se estaba refiriendo a la seguridad como un concepto prevencionista que surgiría más adelante, sino a la seguridad como condiciones jurídicolaborales ${ }^{43}$, sinónimo de estabilidad en el empleo.

A su vez, cuando aludía a "condiciones de seguridad social», lo hacía refiriéndose a las correspondientes a altas, bajas, cotización y demás de obligado trámite en lo competente a la Seguridad Social en sí y no a la seguridad estructural de la empresa.

La doctrina además de profundizar en estos defectos ya comentados, se dividió en su interpretación. Una corriente entendía que eran distintos los Bienes Jurídicos protegidos en cada uno de los apartados del artículo 499 bis, mientras que otro sector, detectaba uno solo

${ }^{41}$ Que recoge, "Es también infracción de resultado, pues, para su consumación, es indispensable que efectivamente se haya conseguido abolir o menoscabar, suprimir o limitar, los citados beneficios legales, siendo posible pues la concurrencia de formas imperfectas de ejecución, pudiéndose agregar, para lo que aquí interesa, que, precisamente, uno de los medios o procedimientos que suele citar la doctrina como ejemplo de conducta típica, es la firma, anticipada y obtenida fraudulentamente, de despido voluntario, liquidación y finiquito»-Fragmento del Considerando Tercero de la Sentencia del Tribunal Supremo de 14 de marzo de 1985- RJ 1985/1647-.

${ }^{42}$ Quintano Ripollés, A., Tratado de la Parte Especial del Derecho Penal... cit., pág. 183.

${ }^{43}$ Rodríguez Devesa, J.M., Derecho Penal Español... cit., pág. 311. 
bien. Autores como Muñoz Conde ${ }^{44}$ defendían que el Bien Jurídico en el párrafo $1 .^{\circ}$ era la libertad, el del $2 .^{\circ}$ la seguridad, el del $3 .^{\circ}$ las disposiciones administrativas sobre tráfico de mano de obra, y el del párrafo $2 .^{\circ}$ del mismo, los derechos de crédito de los trabajadores. Mientras, la otra corriente, entendía que nos encontrábamos ante la protección de un mismo objeto donde cada párrafo orientaba su labor protectora hacia determinadas vertientes del mismo. Así, Arroyo ${ }^{45}$ estimaba que el Bien Jurídico protegido era el interés del Estado en que se respetaran las condiciones mínimas de vida profesional de los trabajadores por cuenta ajena, también resumía Bustos «los derechos del trabajador» individualizables en distintos subtipos mientras Lascuraín Sánchez ${ }^{46}$ se mostraba partidario de esta opción también, con la determinación de un Bien tutelado único, la indisponibilidad contractual in peius de los derechos de los trabajadores reconocidos por disposición legal o convenio colectivo sindical.

Pues bien, si la discusión doctrinal estaba centrada entre la existencia de un único Bien o en darle a cada uno de estos subtipos una autonomía propia decantándose por la opción de la pluralidad de Bienes, la jurisprudencia resolvió el dilema decantándose de forma unánime por la primera de las opciones.

Mencionemos dos Sentencias especialmente significativas con las que identifico mi opinión acerca del tema: la STS de 14 de marzo de 1985 que afirma que el bien jurídico protegido «es la seguridad del trabajador en el mantenimiento del empleo y demás condiciones de trabajo ante maquinaciones fraudulentas encaminadas a lograr un fraude de ley» ${ }^{47}$ defendiendo una visión unitaria del bien tutelado pero con la posibilidad de en cada subtipo, recogido en cada párrafo, concretar una versión específica de ese bien único; y la STS 4 de mayo de 1990 que crea un valioso precedente cuando afirma que no se vulnera el principio acusatorio al ejercer la acción penal por un delito previsto en uno de los párrafos del artículo 499 bis y condenar por otro tipificado en distinto párrafo por la homogeneidad de sus contenidos por la «idéntica protección penal de los mismos, el bien jurídico tutelado es uno sólo, las condiciones laborales de los trabajadores

${ }^{44}$ Derecho Penal. Parte Especial..., cit., pág. 100.

${ }^{45}$ Manual De Derecho Penal Del Trabajo..., cit., pág. 24.

${ }^{46}$ La Protección Penal ..., cit., pág.62.

${ }^{47}$ Sentencia del Tribunal Supremo de 14 de marzo de 1985 -RJ 1985/1646-que afirma que el precepto protege un bien común que podrá concretarse en cada uno de sus párrafos, para definir de forma más concreta, el objeto de tutela.

Sentencia comentada de forma muy ilustrativa por Luzón Cuesta, J.M., en Compendio De Derecho Penal. Parte Especial, Ed. Dykinson, Madrid, 2007, pág. 146. 
reconocidas en disposición legal o convenio sindical estableciéndose en los párrafos $2 .^{\circ}, 3^{\circ} 1$ y 2, tan sólo formas especiales de realización dentro del mismo delito, o lo que es lo mismo, subtipos que atienden al mismo bien protegido» ${ }^{48}$.

En otro orden, no todos los llamados delitos sociales ${ }^{49}$ recogidos en este artículo 499 bis entraban en la protección penal, sino sólo como hemos visto, los que hubieran sido reconocidos en disposiciones «legales o en convenios colectivos sindicales». Se tutelaban pues, los derechos que emanaban entonces de: las Leyes Ordinarias; Decreto Ley; Reglamentaciones del Trabajo (que en nuestro país constituían la más importante fuente de la fijación de condiciones de trabajo); de los Reglamentos Ordinarios (que desarrollaban una Ley anterior); y de los Reglamentos de régimen interno ${ }^{50}$.

En cuanto a otras fuentes legales Sainz Cantero ${ }^{51}$ matizó que serían además objeto de protección para el trabajador los derechos reconocidos por Leyes Fundamentales y Leyes de Bases cuando estuvieran reconocidas por Leyes Ordinarias; en las Normas Preceptivas y las de Obligado Cumplimiento y; en las Sentencias Normativas mediante las que, la Jurisdicción Laboral habría de resolver conflictos colectivos de trabajo -artículo 1 de la Ley de Procedimiento Laboral, Texto Refundido de 21 de abril de 1966-. Estas Sentencias contendrían pues, las reglas de interpretación de carácter general aplicables ${ }^{52}$ a todos los afectados por la norma o convenio, en las Normas Jurídicas Complementarias y en los Convenios Colectivos Sindicales sin dejar de observarse que estos Convenios lo eran si se celebraban conforme a lo dispuesto en el artículo 3 de La Ley de Convenios Colectivos Sindicales, con lo que quedaba en definitiva fuera de la protección penal del 499 bis los derechos emanados entre otros, de la vía contractual, de los Convenios de ámbito inferior o de órdenes de desarrollo, no dejando

${ }^{48}$ Sentencia del Tribunal Supremo de 4 de mayo de 1990 -Núm. de Recurso 4516/1987-, y por la que no hubo indefensión porque se acusó de un delito típicamente más amplio y penado con pena más grave -art. 499 bis.3.2- que aquél por el cual se condenó -art. 499 bis.2-, siendo ambos delitos protectores de un mismo bien jurídico.

Es decir, al acusarse por el más grave, hubo una acusación implícita por el más leve, y al defenderse de todos los elementos de aquel definido con mayor amplitud existió defensa respecto del que contenía un requisito menos.

${ }^{49}$ Valle Muñiz J.M. y Villacampa Estiarte, C., en Comentarios al Nuevo Código Penal..., cit., pág. 1449.

${ }^{50}$ Borrajo Dacruz, E., Derecho del Trabajo, Ed. Doncel, Madrid, 1970, pág. 337.

${ }^{51}$ En Torno a los Delitos Contra la Libertad y Seguridad en el Trabajo..., cit., pág.6.

${ }^{52}$ Alonso Olea, M., Casos Prácticos de Derecho del Trabajo, Ed. Universidad Complutense de Madrid, Madrid, 1973, pág. 125. 
de ser ésto perjudicial para el trabajador si se realizaba una interpretación estricta en este sentido del artículo. Y como no, esta exclusión no pasó desapercibida para la crítica doctrinal así como tampoco, ayudó a que el precepto se aplicara de forma más eficaz, de manera que esta restricción la defienden Sentencias, como la Sentencia del Tribunal Supremo de 13 de junio de $1975^{53}$ argumentando que de esta forma, la penalidad no regía para todas las infracciones de las condiciones laborales sino sólo para «las más intolerables».

Y es que, recordemos que comentamos un artículo de una época preconstitucional con el matiz social y político que tenemos que considerar pero aún así, ofensivo sería a mi entender para el trabajador distinguir entre infracciones de las condiciones laborales más «tolerables» o menos "tolerables». La utilización de este término la considero del todo inidónea, ya que nos plantea dónde trazar esta línea de diferenciación sin dejar al trabajador como víctima desprotegido en algún momento. Sainz Cantero ${ }^{54}$ observó al respecto que la tutela de este artículo no estaba en contra de cualquier ataque sino sólo frente a aquellos actos que tuvieran una especial intensidad requerida por el dolo por, la preceptiva necesidad de ser fruto de un procedimiento malicioso e intencionado ${ }^{55}$. De manera que la intencionalidad del sujeto obligaba a realizar una interpretación extensiva y analógica de un concepto tan subjetivo e íntimo dejando a una generalizada opinión de la doctrina científica de la época criticando la necesidad de concretar en la norma los indicios del ánimo doloso del actor, ya que el párrafo $2{ }^{\circ}$ con la expresión, «el que por cesión de mano de

${ }^{53}$ Concretamente, el Considerando Tercero de la Sentencia del Tribunal Supremo (de junio de 1975 -JUR 2867-) determina que, «El delito descrito en el artículo 499 bis del vigente Código Penal, creado por la Ley de Reforma del mismo, de 15 de noviembre de 1971, y que figura intercalado en el título XII del dicho Cuerpo Legal sustantivo, bajo la rúbrica de Delitos contra la Libertad y Seguridad en el Trabajo, tiene por finalidad la protección penal de los derechos reconocidos a los trabajadores en la legislación laboral y convenios colectivos sindicales, para evitar la vulneración de las condiciones de estabilidad y seguridad en el empleo por parte de los empresarios o dadores de trabajo en abuso de su privilegiada situación económica y susceptibles de alterar la normalidad y equilibrio de las relaciones entre el capital y el trabajo necesarias para el mantenimiento de la producción y de la paz pública si bien dicha criminalización no rige para todas las infracciones de las condiciones laborales sino que solamente debe ser aplicada a ciertas conductas consideradas como socialmente intolerables que constituyan aquellos delitos llamados de explotación del hombre por el hombre, para tipificar cuales, el legislador ha tenido que acudir a exigir conductas de fraude que generalmente van acompañadas de imposiciones, coacciones o como fija más expresamente el citado precepto, de maquinaciones o procedimientos maliciosos, que determinan por parte del trabajador la obligación de soportar situaciones que perjudican a sus derechos.»

${ }^{54}$ En Torno a los Delitos..., cit., pág. 12.

${ }^{55}$ Bajo Fernández, M., Derecho Penal Económico, Ed. Civitas, Madrid, 1978, pág. 524. 
obra, simulación de contrato, sustitución o falseamiento de empresa o cualquier otra forma maliciosa» no concretaba cómo distinguir con claridad esa intención dolosa del autor. De forma que estas formas enumeradas sólo a modo de ejemplo, acabaron siendo consideradas como de numerus apertus por el Tribunal Supremo, pudiendo ampliarse además, según permitía esa fórmula abierta final, la expresión «cualquier otra forma maliciosa».

Y como podemos observar a la reiteración del dolo como requisito se añadía también la exigencia del resultado inmediato consumado en la imposición de condiciones, ya por una acción o por una omisión, contrarias a los derechos de los trabajadores recogidas en las disposiciones legales o Convenios Colectivos sindicales y tal que así, venía reiterado por Sentencias como la Sentencia del Tribunal Supremo de 5 de febrero de 1981 y la de 18 de mayo de $1981^{56}$ donde se calificaba este delito como de "consumación instantánea» porque se consumaba en el momento de la imposición de las referidas condiciones y se mantenía en el tiempo mientras tales condiciones subsistían. Se entendía que para realizar el delito no era necesario pues, la materialización del resultado en un menoscabo físico, moral o económico sino tan sólo, bastaba con que ese daño se proveyera futuro y potencial después de haber dispuesto al trabajador condiciones perjudiciales contrarias a la ley. La materialización del daño en un perjuicio real pertenecería entonces no a la fase de perfeccionamiento sino a la de agotamiento del delito.

Pero, el delito laboral que como comentamos pretendió otorgar una protección especial al trabajador cuando se realizaba mediante

${ }^{56}$ Sentencias de referencia RJ 1981/479 y RJ 1981/2235, respectivamente, citadas a modo de ejemplo, y por las que, aún determinando la perfección del delito ya en el momento de imposición de las condiciones perjudiciales para el trabajador, además se concretaban sus elementos constitutivos en: «a) la supresión o restricción de los beneficios de la seguridad en el empleo y demás condiciones de trabajo legalmente reconocidas, lo que presupone la existencia de una relación laboral normal en que se reconozcan estos derechos; $b$ ) que estos derechos correspondan a la seguridad en el empleo y demás condiciones a su favor establecidas y reconocidas de los que la seguridad en el empleo representa un principio general básico del Derecho de trabajo; c) que la supresión o restricción de tales derechos se produzcan maliciosamente, de cuyas modalidades la cesión de mano de obra, o sea, la puesta a disposición por un empresario de trabajadores en favor de otro, causante de posibles fraudes, tiende a evitar, y en su caso a sancionar que el trabajo humano sea considerado como una pura mercancía al contratarse o comerciarse el esfuerzo ajeno sin respeto a los más esenciales principios de la dignidad humana, en manifiesto abuso de las disposiciones que amparan y regulan las relaciones laborales; $y$ d) que se obre maliciosamente, sin que en su comisión pueda entrar la imprudencia o negligencia, por ser delito de carácter doloso» (fragmento de la Sentencia del Tribunal Supremo de 18 de mayo de 1981). 
el delito común parecía que quedaba absorbido por el contenido en el artículo 499 bis, según el principio de especialidad, por tanto con un concurso de normas sujeto a dicho principio y no al de alternatividad previsto en el artículo 68 del Código Penal de la época. Esta solución desvirtuaba así, ese plus de protección pretendido ya que, en muchos casos como es en el de la falsedad documental (artículo 306) la pena aquí prevista era mayor que la determinada en el artículo 499 bis $2 .^{\circ}$ quedando por esta última, relegada la acción delictiva con el consecuente beneficio, para el autor.

Ahora bien, atendiendo mejor al bien jurídico protegido habría que solucionar ésto, como así lo indicó una corriente doctrinal y jurisprudencial mayor, con un concurso de delitos de los previstos en el artículo 71 del Código Penal. Así lo resumía la Sentencia del Tribunal Supremo de 13 de abril de $1976^{57}$ y de manera más reciente, la de 21 de diciembre de $1987^{58}$ y la de 23 de diciembre de $1989^{59}$

${ }^{57}$ Aunque la Sentencia del Tribunal Supremo de 13 de abril de 1976 -JUR 1624-, utiliza una terminología acorde a la época cuando describe, en el Considerando Tercero, el delito contra la libertad y seguridad en el trabajo, como un «delito de explotación».

${ }^{58}$ Sentencia del Tribunal Supremo de 21 de diciembre de 1987 -RJ 1987/9814-, por la que, «el delito laboral se otorga una protección especial al trabajador, cuando el tipo se realice mediante un delito común, parece, en principio que este quedará sorbido en aquel a virtud del principio de especialidad y que, por tanto, se dará un concurso de normas sujeta a dicho principio y no al de alternatividad previsto en el artículo 68 del Código Penal. Pero tal solución desvirtuaría totalmente el norte de aquella protección que implica un plus sobre la ordinaria, de suerte que si las condiciones de trabajo se alteran mediante falsedad documental, caso repetido en la praxis, dicha falsedad penada más gravemente por el artículo 306 del Código Penal quedaría desplazada por el artículo 499 bis.2. ${ }^{\circ}$ que impone pena inferior, no obstante añadir a dicha falsedad el aliud del perjuicio laboral, lo cual quiere decir que al proteger uno y otro precepto bienes jurídicos distintos, se dará un concurso de delitos a resolver por el artículo 71 del Código Penal tal como entendió la Sentencia de 13 de abril de 1976 ( RJ 1976/1624) rectificando la de 23 de marzo del mismo año (RJ 1976/1256) que aplicó el artículo 68 del Código Penal como concurso de normas, doctrina la contenida en la primera de dichas sentencias que debe prevalecer, de acuerdo con el apoyo de la doctrina más especializada».

${ }^{59}$ Sentencia del Tribunal Supremo de 23 de diciembre de 1989 -RJ 1987/9973-, que con el mismo criterio, estima que "el concurso ideal delictivo en su modalidad medial exige ontológicamente la nota de «necesariedad». El motivo debe ser analizado conjuntamente con los inmediatamente siguientes: cuarto y quinto; todos ellos apoyados procesalmente en el mismo precepto procesal y que respectivamente denuncian la vulneración por aplicación indebida de los artículos 303/302 (el cuarto), 499 bis (el quinto) del Código Penal. Todos ellos se imbrican en una misma dirección impugnativa y por ello deben ser tratados conjuntamente con el motivo séptimo, que con el mismo apoyo procesal denuncia la vulneración del art. 306 del Código Penal, por inaplicación alegando la idoneidad de reputar existente la calificación de documento público por incorporación del documento falso en virtud de la norma contenida en el artículo 304 del Código Penal; alegación previa que, en su conexión sistemática con la norma contenida en el artículo 307 del repetido Código conlleva la conclusión necesaria en orden 
del mismo Tribunal, que marcaban este criterio más acorde con el espíritu protector de la reforma.

De cualquier modo, analizaremos más adelante con detenimiento la cuestión del concurso de delitos ya que, es un problema que también alcanza con igual sentido, hasta nuestra regulación actual.

Es de destacar además, y siguiendo con el artículo 499 bis, que por lo que respecta al sujeto activo en él considerado, va a ser el empresario o «dador del trabajo»-según entre otras Sentencias, la ya mencionada Sentencia del Tribunal Supremo de 5 de febrero de 1981 y la de 15 de Octubre de $1982^{60}$ - o cualquier otra persona que participara en la acción delictiva en calidad de inductor o cooperador según artículo 14 del propio Código vigente en aquel momento, apuntando incluso, la Sentencia del Tribunal Supremo de 28 de junio de $1977^{61}$ la consideración de cooperadores necesarios y con ésto autores, a los miembros del Jurado de Empresa como órgano directivo de la misma por su implicación directa en la toma de decisiones. Y es que, de forma acertada la Sentencia del T.S de 22 de diciembre de 1990 resume que la capacidad para la imposición de condiciones que da contenido al tipo la podrá ostentar cualquier persona dentro de la estructura jerárquica de la empresa «con poder decisorio en este ámbito» ${ }^{62}$.

al razonamiento excluyente de la publicación (permítase el barbarismo lingüístico) del documento, pues un solo hecho no puede en caso alguno dar lugar a dos tipificaciones distintas conforme al principio de legalidad establecido en el artículo 25 de la Constitución y el principio de especialidad derivable del artículo 68 del Código Penal».

${ }^{60}$ Sentencia del Tribunal Supremo de 15 de octubre de 1982 -RJ 1982/5639 que establece, "el sujeto activo ha de ser un empresario o empleador-terminología esta última, que, con dudoso acierto, introduce el vigente Estatuto de Trabajadores-, habiendo de tenerse por tal empresario, cuando se trata de persona jurídica-"societas delinquere non potest $\gg$, a los administradores o encargados individuales del servicio que hubieran cometido la infracción o que, conociéndola y pudiendo hacerlo, no hubieran adoptado medidas para evitarla».

${ }^{61}$ En el Considerando Primero de la Sentencia del Tribunal Supremo de 28 de junio de 1977 -JUR 2965-, se hace constar que «... El delito que define y sanciona el núm. 2 del art. 499 del C.P., es un delito propio, que en principio sólo puede ser cometido por quienes ostenten la condición de empresario, la responsabilidad criminal en concepto de autor puede alcanzar a quienes no tengan la condición de empresario por vía de la participación necesaria del núm. 3 del artículo 14 del propio Código, por lo que, aunque los procesados no tienen la cualidad de empresario y sí la de miembros del Jurado de Empresa, su incriminación por el expresado delito sería viable por el indicado cauce».

62 Sentencia del Tribunal Supremo de 22 de diciembre de 1990-RJ 1990/10005, que afirma un criterio fáctico y en ningún momento formal, para la atribución de responsabilidades, al condenar a la imputada en virtud, "no solamente de su cualidad de administradora de la sociedad anónima infractora, sino por ser quién ostenta "poder 
Pues bien, pese a su esforzada formulación, y debido principalmente a sus imprecisiones, su requerimiento del dolo, los problemas concursales que presentaba, su articulación como norma penal en blanco, su carácter de delito de consumación instantánea, y demás defectos descritos, la aplicación del artículo 499 bis por la jurisprudencia fue prácticamente nula al menos, en atención a interpretar la falta de condiciones de seguridad e higiene contenidas en las condiciones laborales aludidas. No por casualidad, Sainz Cantero afirmó que nos encontrábamos ante un "precepto de papel» ${ }^{63}$ y Gimbernat llegó a denunciar que ante este artículo la actitud de escepticismo era la más realista ${ }^{64}$.

En este sentido la Sentencia TS de 29 de mayo de 1989 con especial interés resume que «la jurisprudencia que se ha ocupado del tema en Sentencias de 13 de junio de 1975, de 24 de febrero, 23 de marzo y 13 de abril de 1976, de 20 de mayo y 28 de junio de 1977, 22 de junio de 1979, 2 de febrero y 30 de abril de 1980, 18 de mayo de 1981, 15 de octubre de 1982, 14 de marzo de 1985 y, 21 de octubre de 1987, bautiza, a las infracciones estudiadas, con la denominación de delitos de explotación-Sentencia de 13 de abril de 1976-o de delitos de explotación del hombre por el hombre-Sentencia de 13 de junio de 1975-, afirmando que, el bien jurídico protegido, es la seguridad jurídica del trabajador en el mantenimiento del empleo y demás condiciones del trabajo y que, la reforma, propende a cohibir y castigar, las maquinaciones o asechanzas artificiosas, tendentes a lograr un fraude de ley, dando apariencia de legalidad a lo que realmente no lo es» ${ }^{65}$ con lo que en definitiva, plantea la aplicación del precepto para el control del cumplimiento de condiciones laborales relacionadas con la seguridad jurídica del trabajador que evitan su explotación pero no su inseguridad preventiva en lo que respecta a los riesgos que estudiamos, del todo como vemos, ausentes en la interpretación jurisprudencial del artículo.

Y es que, tendríamos que esperar un poco más de tiempo, para encontrar una formulación eficaz del delito contra la seguridad e higiene en el trabajo, el siguiente por orden cronológico, el artículo 348 bis.a), precedente inmediato de nuestra actual regulación penal y con el que la Ley Orgánica de 15 de junio de 1983 intentó

decisorio y la gestión de la misma", y a la que únicamente podían imputarse los actos constitutivos del delito».

${ }^{63}$ En Torno A Los Delitos..., cit., pág. 30.

${ }^{64}$ La Reforma del Código Penal de noviembre de 1971, en Estudios de Derecho Penal, Ed. Civitas, Madrid, 1981, pág. 69.

${ }^{65}$ Sentencia del Tribunal Supremo de 29 de mayo de 1989 -RJ 1989/4271-, que se refiere en todo momento, a la seguridad en el empleo para el trabajador, como garantía pero nunca, como medida preventiva en relación con los riesgos laborales. 
satisfacer las más apremiantes exigencias de un Derecho Penal ajustado a aquel momento histórico. Seguidamente nos ocuparemos de este artículo y de las innovaciones que aportó.

\section{ETAPA DEMOCRÁTICA}

Siendo ya el nuestro un Estado de Derecho ${ }^{66}$ por la aprobada Constitución de 1978 donde recordemos que se incluye el artículo 40.2 que asegura que los Poderes Públicos han de garantizar entre otros derechos, la seguridad e higiene en el trabajo, cobrando esencial importancia en esta etapa el cuidado del trabajador. Además, coetáneo a esta época, se aprobó el Estatuto del Trabajador de 10 de marzo de 1980 que exponía en su artículo 4.2 d) que «en la relación de trabajo los trabajadores tienen derecho a su integridad física y a una politica de seguridad e higiene y en el 19 que el trabajador en la prestación de servicios tendrá derecho a una protección eficaz en materia de seguridad e higiene».

Por su parte, en el Proyecto de Código Penal de 1980, en el Título I, Libro II de los Delitos contra la Vida e Integridad Personal, Capítulo IV, en Disposiciones Comunes encontramos el artículo $176^{67}$ que expresamente endurecía la pena cuando el resultado lesivo o de muerte fuera originado por la infracción grave y reiterada de las normas de seguridad e higiene en el trabajo ${ }^{68}$. Si bien, la apariencia del precepto era que el ánimo del legislador había sido proteger la seguridad en el trabajo, la realidad era que tan sólo se articulaba como un tipo agravado sobre la base del artículo precedente $175^{69}$, endureciendo la pena a la mitad de su máximo, en el caso que la vida y salud de las personas se vieran dañadas con infracción de las normas de seguridad e higiene.

${ }^{66}$ Martín Valverde, A., El Ordenamiento Laboral en la Jurisprudencia del Tribunal Constitucional, Revista Política Social, núm. 137, 1983, págs. 120 y ss.

${ }^{67}$ Artículo 176. "Cuando la muerte o las lesiones graves fueren causadas por impericia o negligencia profesional, o por infracción grave o retirada de las normas de higiene y seguridad en el trabajo, los Tribunales impondrán las penas previstas en el articulo anterior para los supuestos de imprudencia grave, sin que pueda bajar la mitad de su máximo».

${ }^{68}$ Rivera Hernández, J.M., La protección penal de los derechos laborales reconocidos en la Constitución, Ed. Instituto de Estudios Sociales, Madrid, 1980, pág. 20.

${ }^{69}$ Artículo 175. "El que por imprudencia causare la muerte de otro, será castigado, como reo de homicidio culposo, a la pena de prisión de dos a cuatro años si la imprudencia fuere grave, y de seis meses a dos años o arresto de seis a veinticuatro fines de semana si fuere leve.

Si causare lesiones graves, la pena será de prisión de seis meses a dos años o arresto de doce a veinticuatro fines de semana si fuere leve». 
Pues bien, con este panorama se podía intuir que existía una preocupación política y social hacia el tema de nuestro estudio pero la protección de los trabajadores por la falta de medidas de seguridad requería de un tipo especial para no sólo presentarse como una agravación de un precepto más amplio, permitiendo así que se perdiera el posible efecto intimidatorio de esta agravación, al estar supeditada a la realización de la muerte o las lesiones del artículo 175.

Nació así, sin perjuicio de la subsistencia del artículo 499 bis, el artículo al que ya hemos hecho referencia, 348 bis a $)^{70}$, de estructura claramente omisiva que no exigía el grado de intencionalidad de su anterior regulación y que pretendía la prevención del daño. El delito consistía ahora materialmente en la puesta en peligro de la vida e integridad de los trabajadores por infracción de las normas de seguridad en el trabajo por parte de quienes estaban obligados a su cumplimiento, protegiendo de modo específico la seguridad en el trabajo ahora sí, entendida con un concepto preventivo.

Del estudio sistemático tanto de la doctrina ${ }^{71}$ y jurisprudencia que analizó su aplicación, podríamos concluir que casi con unanimidad se señaló que el Bien Jurídico protegido en este artículo era la seguridad e higiene en el trabajo ${ }^{72}$ que extiende su protección a los trabajadores, ante meramente supuestos de peligro para su vida o integridad física. Ahora bien, así como la regulación de 1928 mencionaba expresamente «la salud», aquí se omitía esa alusión directa cosa que la doctrina terminó por justificar entendiendo que se trataba de un error involuntario del legislador dado que del espíritu que inspiró la reforma del que este artículo era fruto y del que se deducía el ánimo protector máximo de su contenido, con lo que se realizó una interpretación amplia del «peligro para la vida» que podía suponer la falta de medidas de seguridad e higiene equiparando la falta de salud al deterioro de la vida. Así,

${ }^{70}$ En la Sección 3. a del Capítulo II, de los «Delitos de riesgo en general», del Título V, Libro II de los «Delitos y sus penas», dedicada a los "Delitos contra la seguridad en el trabajo», se incluye este 348 bis.a) que versa "Los que estando legalmente obligados no exijan o faciliten los medios o procuren las condiciones para que los trabajadores desempeñen una actividad con las medidas de seguridad e higiene exigibles, con infracción grave de las normas reglamentarias y poniendo en peligro su vida o integridad física serán castigados con la pena de arresto mayor -un mes y un día a seis meses- $o$ de multa de 30.000 a 150.000 pesetas» -cuantía que la Ley 3/1989, de 21 de junio, modificó subiendo a 100.000 a 500.000 pesetas y, seguimos refiriéndonos a esta moneda para respetar la redacción de la época-.

${ }^{71}$ Muñoz Conde, F., La Reforma Penal de 1989, Ed. Tecnos, Madrid, 1989, pág. 150. Fernández Marcos, L., La seguridad e higiene..., cit., pág. 19.

${ }^{72}$ Arroyo Zapatero, L. Manual de Derecho Penal del Trabajo..., cit., págs. 154 y ss. 
la jurisprudencia y la doctrina ${ }^{73}$ reiteraron que la interpretación de «seguridad e higiene en el Trabajo» habría de ser concebida como ausencia de riesgos para la vida, salud e integridad física del trabajador aunque el precepto sólo recogiera la «vida e integridad física».

Por su parte, el sujeto activo tenía que estar «legalmente obligado» a proteger el bien jurídico lo que convertía esta infracción en un delito especial propio, de forma que estaban legalmente obligados aquellas personas a las que se le imputaba el deber laboral de seguridad e higiene en el trabajo siendo responsable directo el que omitiera su deber $^{74}$. Era pues un delito Propio ya que del artículo se derivaba que los «legalmente obligados» eran el empresario y todas aquellas personas que por designación de éste asumían en el esquema organizativo de la empresa, facultades de mando sobre otros trabajos y capacidad de resolución propia, en el entorno donde se encontraba la fuente de peligro. Para ésto, la jurisprudencia insistió en recurrir al término "encargados» con el criterio de que eran aquellos quienes efectivamente asumían en un momento dado el poder de dirección empresarial.

Muy importante resultaba además, la observación de que al ser la conducta típica no exigir y no facilitar los medios o no procurar las condiciones para que los trabajadores desempeñaran una actividad con las medidas de seguridad exigibles, tendrían que ser los sujetos «legalmente obligados» a exigir, facilitar o procurar, los presuntos autores del delito recogido en el 348 bis.a), con lo que para un completo estudio tendríamos que acudir al estudio de los artículos 10 y ss. de la Ordenanza General de Seguridad e Higiene en el Trabajo, de preceptiva aplicación en el momento, donde se recogían las obligaciones específicas del empresario, del personal directivo y técnico y de los mandos intermedios.

Por su parte, la conducta recogida en el 348 era como hemos apuntado, esencialmente omisiva, por comisión por omisión ${ }^{75}$ y así como en la anterior regulación del artículo 499 bis se exigía el resultado éste, era por fin un delito de peligro concreto provocado por omi-

${ }^{73}$ Fernández Marcos, L., La seguridad e higiene..., cit., pág. 8.

${ }^{74}$ Esta opción la reiteraban en ese momento los artículos 7.1 y 2 de la Ordenanza General de Seguridad e Higiene en el Trabajo de 9 de marzo de 1971 que designaban al empresario y a «todas las personas que por su delegación asumieran la facultad de mando», extendiendo así de nuevo la posibilidad de imputación del delito a otras personas que no fueran estrictamente el empresario.

${ }^{75}$ Carmona Salgado, C. y Cobo del Rosal, M., Manual de Derecho Penal. Parte Especial, Ed. de Derecho Reunidas, Madrid, 1994, pág. 212. Rodríguez Devesa, J.M., Derecho Penal Español. Parte Especial..., cit., pág. 1.117. 
sión pudiendo consistir, tanto en no exigir o no facilitar medios como en no procurar las condiciones para que los trabajadores desempeñaran su actividad con las medidas de seguridad e higiene exigibles.

De estas tres modalidades las dos primeras se referían a un mismo objeto, «los medios de seguridad», entendiendo éstos como medios que han de ser empleados por los trabajadores, medios de protección personal ${ }^{76}$ que el empresario y sus encargados habrían de facilitar a los empleados. Mientras que por «condiciones de seguridad», habría de entenderse los presupuestos personales, materiales y organizativos de la prestación del trabajo que evitaran la creación de riesgo o neutralizaran o aminoraran los ya existentes exigidos por las normas de seguridad ${ }^{77}$.

Básicamente las tres formas, no exigir, facilitar o procurar, redundaban en la necesidad de tener un nexo causal con la creación de un peligro por infracción de estas normas de seguridad impuestas por el ordenamiento. La doctrina por su lado, criticó especialmente el que se pudiera interpretar que si las normas de seguridad se incumplían por medios distintos a los referidos «no exigir, facilitar $o$ procurar», la conducta podría ser considerada atípica ${ }^{78}$.

Además tal omisión habría de conllevar, una infracción grave de las normas reglamentarias que pusiera en peligro la vida o integridad física del trabajador. La conducta omisiva tendría relevancia penal cuando se infringía de forma grave tal regulación con lo que esa regulación extrapenal sería la que decidía si estábamos ante una conducta delictiva o no. De nuevo, una ley penal en blanco, con la problemática que conllevaba su consideración.

El mayor problema en la interpretación de este precepto penal en blanco era, como ocurre igualmente en la regulación actual, que la tutela penal iba a venir condicionada por esa norma de referencia de

${ }^{76}$ Arroyo Zapatero, L., Manual de Derecho Penal..., cit., pág. 158. Fernández Marcos, L., La Seguridad e Higiene..., cit., págs. 30 y 31. Lascuraín Sánchez, J.A., La Protección Penal de..., cit., pág. 323.

${ }^{77}$ Arroyo Zapatero, L., Manual de Derecho Penal..., cit., pág. 159. Fernández Marcos, L., La Seguridad e Higiene..., cit., pág. 31. Lascuraín Sánchez, J.A, La Protección Penal de..., cit., págs. 305 y 323 a 326.

${ }^{78}$ Lascuraín Sánchez, J.A, La Protección Penal de..., cit., pág. 301. Fernández Marcos, L., La seguridad e higiene..., cit., pág. 21. García Arán, M., La Protección Penal de la Seguridad en el Trabajo en el Código Penal vigente y en el Proyecto de Código Penal de 1992 en Derecho Penal del Trabajo y Derecho Administrativo Sancionador, Ed. Universidad de Cádiz, Cádiz, 1992, pág. 24. Muñoz Conde, F., Derecho Penal. Parte Especial..., cit., págs. 343 y ss. Terradillos Basoco, Derecho Penal de la Empresa, Ed. Trotta, Madrid, 1995, pág. 126. 
naturaleza extrapenal encontrándonos ante la incertidumbre que conllevaba la constante puesta en duda de la inconstitucionalidad de este recurso ${ }^{79}$ y la inseguridad jurídica que podía conllevar la necesidad de remitirnos a una regulación extrapenal para concretar la existencia del tipo punible en vía penal ${ }^{80}$. Una inseguridad acrecentada además por el desorden, la dispersión y el caos que en esa época caracterizaba a la normativa laboral de referencia y que quizás, tuvo que revisarse de forma previa a la entrada en vigor de este artículo 348 bis a).

Por otro lado, la infracción habría de realizarse según el precepto, de forma "grave» entendiendo como grave no cualquier infracción sino aquella relevante respecto a tales peligros terminología que, no dejaba de ser imprecisa e incierta con el riesgo para el sujeto

${ }^{79}$ Por citar un ejemplo, a favor, Terradillos Basoco, J., Derecho Penal de la Empresa..., cit., pág. 126. En contra, García Arán, M., La Protección Penal de..., cit., págs. 27 y 28.

${ }^{80} \mathrm{La}$ infracción grave de las normas reglamentarias excluiría entonces a priori, aquellas no contenidas en disposiciones de Derecho Público: las Normas escritas puramente corporativas; la Lex Artis no escrita de las diferentes profesiones; las meras Normas de experiencia; los Convenios Colectivos; disposiciones singulares adoptadas por el Inspector de Trabajo; todas ellas, disposiciones también necesarias.

Eran pues tan sólo punibles la infracción de las Normas Reglamentarias aludidas en la Ordenanza General de Seguridad e Higiene en el Trabajo y en sus Ordenanzas particulares correspondientes a ramas concretas de actividad laboral con rango de Orden Ministerial -por ejemplo la Ordenanza de 26 de agosto de 1940 sobre iluminación en los centros de trabajo, la Ordenanza de 2 de junio de 1961 sobre cargas a brazo de más de 80 kilos, y la Ordenanza de 6 de febrero de 1971 sobre estibadores portuarios-; las disposiciones relativas a determinados grupos de trabajadores en forma de Decretos como el referido al Trabajo de Mujeres y Menores publicados por Decreto Ley de 15 de agosto de 1927; o los Convenios Internacionales, en especial por su particular relación con la materia, el Convenio núm. 155 de 22 de junio de 1981 sobre «seguridad y salud» de los trabajadores aplicable a todas las ramas de la actividad.

Así, a esta, podemos llamar, discriminación se añadía el que recordemos que en el año 1983, cuando aún no había sido publicada la Ley de Prevención de Riesgos Laborales de 1995 con su ánimo unificador, la legislación reglamentaria de seguridad e higiene en el trabajo adolecía de ordenación y sistematización, estando dispersa en regulaciones aisladas tales como el Estatuto de los Trabajadores vigente en aquel momento, la Ley de la Seguridad Social, la famosa Ordenanza General de Seguridad e Higiene o los Reglamentos de Industria. Y es por este motivo por el que la doctrina salvó este problema para la aplicación del precepto, interpretando de forma extensa esta alusión en principio restrictiva, que señalaba tan sólo la infracción de «reglamentos» como elemento condicionador de la omisión punible.

La referencia laboral la encontramos en esa época de nuevo en la Ordenanza General de Seguridad e Higiene en el Trabajo y más concretamente, en el artículo 156 donde se recogía en su apartado 1, que las infracciones en materia de seguridad e higiene en el Trabajo se calificaban como leves, graves y muy graves y en sus apartados 3 y 4 , se determinaban una serie de elementos a tener en cuenta para esa clasificación, pero en ningún momento se exigía ningún requisito en su valoración de forma que se dejaba su apreciación a expensas del prudente arbitrio de la Inspección de Trabajo. 
pasivo que ésto comportaba y que dejaba la responsabilidad de su correcta interpretación al órgano judicial ${ }^{81}$.

$\mathrm{Y}$ es que en definitiva, esa tipificación clara e inconfundible a la que parece aludir el artículo 348 bis a) de la «infracción grave reglamentaria» sencillamente no existía en aquel momento, con la conculcación del Principio de Seguridad Jurídica, que ello podía comportar.

Mientras, la alusión específica de la «vida o integridad física» fue ampliamente comentada por la doctrina ya que excluía una referencia expresa a la salud, con la consecuente contradicción de nuestra legislación en comparación con la del ámbito europeo que desde la Organización Internacional del Trabajo había definido la salud como la falta de afecciones físicas o mentales y reiteraba a través de la Recomendación núm.164 de 11 de junio de 1981 la obligación del empleador de "proporcionar que el trabajo fuera seguro y no entrañara riesgos para la salud ${ }^{82}$ de los trabajadores».

Había de resultar pues según el tipo, el resultado punible, un peligro como consecuencia causal de la infracción. Se trataba entonces de un delito de peligro concreto y era preciso de forma preceptiva, que ese riesgo tuviera su nexo causal con la falta de medidas. Una interpretación restrictiva nos llevaba a la posibilidad de que sólo cabía la versión dolosa del delito, consistente ésta en la conciencia de la infracción de la norma de seguridad e higiene, de su gravedad y en la intención de mantener a pesar de ello, la actividad laboral, con lo que habría de existir una conciencia de la infracción de la situación de peligro que de esta infracción se derivaba para la vida o la integridad física de los trabajadores y que estuviera expresamente en la decisión del sujeto, el no evitar ese peligro. También se podría apreciar el dolo eventual cuando el sujeto representaba como probable la presencia de una situación de peligro si se vulneraba una norma de seguridad y a pesar de dicha representación, mantenía la decisión de no adoptar la medida de seguridad, aceptando la aparición o incremento del riesgo efectivo.

${ }^{81}$ Carmona Salgado, C., Manual de Derecho Penal..., cit., pág. 212. Boix Reig, J., Delitos de Riesgo en General, en AA.VV, Derecho Penal. Parte Especial, Ed. Tirant lo Blanch, Valencia, 1993, pág. 394. Rodríguez Devesa, J.M., Derecho Penal Español. Parte Especial..., cit., pág. 1.116.

${ }^{82}$ La Organización Mundial de la Salud entendía salud tanto a la física como a la mental. De forma que la «integridad física» de este artículo 348 bis.a), la debíamos entender pues según lo que se definía para el delito de lesiones, como la pérdida de alguna de las partes u órganos corporales dejando fuera las enfermedades tanto físicas como psíquicas por lo que, la corriente doctrinal mayoritaria quiso subsanar este defecto entendiendo que la salud se encontraba integrada en la alusión realizada a la vida, y ser esa vida el pleno disfrute de tanto la salud física como la mental. 
Pues bien, ante esta exigencia de dolo, la versión culposa se castigaba entonces, conforme al conocido artículo $565^{83}$ en su relación con el 348 bis.a ${ }^{84}$, con pena de multa inferior a 30.000 pesetas -según formulación de la época- siendo suficiente según el Principio de Non bis in Idem esta leve multa, para impedir la Sanción Administrativa. Con lo que, en términos intimidatorios para el sujeto activo potencial, entiendo que más hubiera valido entonces, mantener para aquellos casos en los que no aparecía de manera clara el dolo, directo o eventual, una remisión expresa al ilícito administrativo más que a este artículo 565, por el que se mitigaba la consecuencia sancionadora para el autor.

Por todo lo expuesto, la aplicación del artículo 348 bis a) por los Tribunales al igual que la del 499 bis fue realmente limitada por no decir nula, tan sólo encontramos dos sentencias que apliquen la regulación penal aquí estudiada previa a la reforma del año 1995. La primera, condenatoria para los empresarios, la STS de 12 de diciembre de 1994 por la que debatiendo la imputabilidad del equipo de gobierno de una Corporación Local del delito contenido en el 499 bis.1. ${ }^{\circ}$ se realiza una interpretación generosa de lo allí establecido, con respecto a la conducta punible al afirmar que se tiene probada la conducta maliciosa requerida por el tipo para justificar la condena ${ }^{85}$.

${ }^{83}$ Arroyo Zapatero, L., Manual de Derecho Penal..., cit., págs. 165 y 166.

${ }^{84}$ Queralt Jiménez, J. J., Derecho Penal Español..., cit., pág. 465. Baylos Grau, A. y Terradillos Basoco, J., Derecho Penal del Trabajo..., cit., pág. 119. Carmona Salgado, C., Manual de Derecho Penal..., cit., pág. 212.

${ }^{85}$ Ya que «de los datos resalta la maliciosidad del procedimiento utilizado por los responsables de la Corporación Municipal que, sin una causa justificada, trasladan sucesivamente de su puesto de trabajo al querellante imponiéndole condiciones laborales no sólo perjudiciales para su salud, sino francamente vejatorias para su condición profesional sometiéndole a la vigilancia y decisiones de una persona que, según el hecho probado, tenía la condición de vigilante del polideportivo; esta intencionalidad aparece de nuevo a través de la lectura del relato fáctico en el que se afirma que la Sala de lo Contencioso-Administrativo tuvo que suspender la obligación impuesta al recurrente de permanecer permanentemente en el local de la Estación de Tratamiento de Agua Potable que le habia sido impuesta por decisión de los dos querellados aun sabiendo que dicha permanencia era peligrosa y lesiva para su salud. Todo ello sin tomar en consideración decisiones tan inconsistentes y desproporcionadas, por lo menos desde la perspectiva que nos proporciona el relato fáctico, como privarle de la máquina de escribir y de retirarle el complemento específico correspondiente a una mensualidad. En el primer supuesto se le impone además la obligación de redactar los escritos con letra de imprenta, bastardilla o con mayúsculas, lo que evidentemente en muy escasa medida podía contribuir al mejoramiento de la gestión de los servicios que se le habian encomendado».

Sentencia del Tribunal Supremo de 12 de diciembre de 1994 -RJ 1994/9375-, que entiende probada la intencionalidad dañina de los condenados, propia del dolo, al basar esta consideración del elemento intencional, aplicando el «método inductivo» para expresar su convicción sobre los hechos que considera probados. 
La segunda, también condenatoria, es la Sentencia de Sección Segunda de la Audiencia Provincial de Tarragona de 14 de febrerode 1995 y que de forma realmente ilustrativa resume los tipos contenidos en las dos regulaciones estudiadas, del art. 499 bis y del 348. bis.a) ${ }^{86}$.

Pero tenemos que destacar que la mayor parte de las conductas punibles del tiempo de vigencia de estos dos artículos -348 bis a) y 499 bis- se enjuiciaron a través del $565^{87}$, por la dificultad para la acusación, de justificar la apreciación del dolo como elemento subjetivo obligado para la consideración tanto de uno como de otro.

Y la producción jurisprudencial fruto de su aplicación es vasta desde la primera Sentencia que encontramos relacionada con la falta de medidas preventivas en la empresa -STS de 19 de febrerode $1979^{88}$ - hasta la casi coetánea a nuestra actual regulación penal

Y es que de nuevo, el criterio con el que apreciar la voluntad del autor, vuelve a estar a merced del Tribunal conocedor del asunto.

${ }^{86} \mathrm{Al}$ afirmar que «la seguridad en el trabajo se protege actualmente a través de dos tipos delictivos distintos, uno de riesgo y con finalidad de prevención de la vida e integridad física -el 348 bis.a)-, y otro de resultado concreto, que consiste en soportar la imposición maliciosa de condiciones ilegales de trabajo. Todos los elementos constitutivos del primero concurren en el presente caso, pero no así los del segundo, por faltar prueba de la maquinación o procedimiento malicioso que exige el dolo del 499 bis. Por último señalar que ciertamente parece lamentable que del juego de ambos tipos delictivos protectores de la seguridad en el trabajo, y en ausencia del elemento subjetivo de la «malicia» exigida por el art. 499 bis, tan sólo sea posible aplicar la pena correspondiente al delito del art. 348 bis.a), sin derivar responsabilidad civil alguna dada la esencia y estructura propias de este tipo de riesgo, único aplicable en este caso, al faltar la acusación por imprudencia -aún simple antirreglamentaria del 586 bis-que de apreciarse permitiría derivarla; ello sin perjuicio de que -expedita la vía civil-puedan ejercitarse en ella por la viuda e hija perjudicadas las acciones pertinentes a tal resarcimiento».

Sentencia de la Audiencia Provincial de Tarragona de 14 de febrerode 1995 RJ 1995/362, que reitera el problema de convivencia de los dos preceptos, 348 bis a) y 499 bis, y el que la necesidad de su reforma, fuera una cuestión reiterada incluso, desde los Tribunales.

${ }^{87}$ Recordemos que el artículo 565, se introdujo por el Decreto de 14 de septiembre de 1973 núm. 3096/1973 que originariamente establecía, «el que por imprudencia temeraria ejecutare un hecho que si mediare malicia constituiría delito será castigado con pena de prisión menor (párrafo 1. ${ }^{\circ}$ ); y al que con infracción de los reglamentos cometiere un delito por simple imprudencia o negligencia se impondrá la pena de arresto mayor (párra-

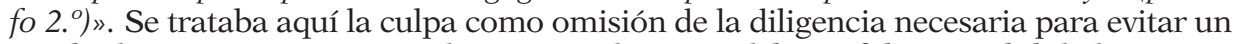
resultado típicamente antijurídico castigado como delito o falta, evitabilidad que presuponía la previsibilidad del resultado al no poderse evitar lo imprevisible. Para su consideración tendríamos que encontrarnos con una acción u omisión no maliciosa, una infracción del deber de cuidado tanto, tanto en su aspecto externo como en el interno, y con un resultado antijurídico producido causalmente por la acción u omisión del autor.

${ }^{88}$ Sentencia del Tribunal Supremo de 19 de febrerode 1979 -RJ 1979/881-, y que al respecto, afirma literalmente que: «en el párr. $2{ }^{\circ}$ núm. 3. ${ }^{\circ}$ del art. 499 bis del C. P., introducido en nuestra normativa penal por Ley de 15 noviembre 1971 (RCL 1971/2050 
de 1995, la Sentencia de la Sección Tercera de la Audiencia Provincial de Barcelona de 10 de mayo de $1994^{89}$.

A modo de ejemplo citaremos tres Sentencias correspondientes con cada tipo de imprudencia temeraria, simple con infracción de reglamentos y sin infracción de los mismos siendo, la imprudencia profesional, la gran olvidada por la jurisprudencia en relación con la falta de condiciones de seguridad en la empresa.

La Sentencia TS de 17 de noviembre de 1992 que aprecia imprudencia temeraria de los socios de una empresa por la omisión de medidas de seguridad ${ }^{90}$; la Sentencia de la Audiencia Provincial de Baleares de 14 de abril de 1994 que no entiende que concurran los requisitos de la imprudencia temeraria pero sí la falta contra las personas por imprudencia simple del aparejador, encargado de obra y director de una constructora $^{91}$, y por último; la Sentencia del Tribunal Supremo de 14

y 2108), con el fin de proteger la libertad y la seguridad jurídica en el trabajo y que se cumplan en todas sus partes los contratos de trabajo y beneficios reconocidos a los trabajadores por disposiciones legales, se necesita la concurrencia de estos dos elementos sustanciales: un elemento subjetivo constituido por el ánimo subrepticio y malicioso tendente a defraudar los legitimos derechos de los trabajadores y, de otra parte, un elemento objetivo, constituido por la realización, para lograrlo, de cualquier actividad, que en caso de crisis de la empresa, sirviera para hacer ineficaces los derechos de los trabajadores mediante el ejercicio de las correspondientes acciones».

${ }^{89}$ Sentencia de la Audiencia Provincial de Barcelona de 10 de mayo de 1994 -RJ1994/212-, que basa su argumentación en que «no resulta admisible, como pretenden los acusadores, que el simple hecho de apreciarse una infracción reglamentaria y la producción de un daño, sea suficiente para imputar el ilícito del art. 348 bis.a); resulta imprescindible acreditar la culpabilidad del agente, es decir que el resultado le sea imputable a título de dolo o culpa y ello debe acreditarse en el ámbito del proceso penal»

${ }^{90}$ Sentencia del Tribunal Supremo núm. 2462/1992, de 17 de noviembre, por la que condena, apreciando imprudencia temeraria en base a, la cualidad e intensidad de la desatención, en función del riesgo desencadenado con la torpe actuación, a la entidad del deber objetivo de cuidado omitido, a las generales circunstancias cognoscibles por el ciudadano medio y, a las reglas experienciales o reglamentadas que marcan la pauta de procedencia en el obrar del sujeto, y justifica esa apreciación al afirmar que, "las diversas especies de culpas que, articuladas en varios tipos, representan una escala jerárquica en cuya cúspide estructural, como la más grave de las infracciones, figura la imprudencia temeraria, suponiendo la misma la eliminación de la atención más absoluta, la inadopción de los cuidados más elementales o rudimentarios exigidos por la vida de relación, suficientes para impedir o contener el desencadenamiento de resultados dañosos previsibles, infringiéndose deberes fundamentales que atañen a la convivencia y a principios transidos de alteridad».

91 Sentencia de la Audiencia Provincial de Baleares de 14 de abril de 1994 ARP 1994/455, en la que de nuevo, se utiliza la comparación con la respuesta exigible a persona consciente, de prudencia e inteligencia medias, así como también, el conjunto de reglas de común experiencia e impuestas por la vida social, "en cuyo escrupuloso entendimiento cifra la Comunidad la conjura del peligro dimanante de la actividad concreta y su suficiencia para impedir el desencadenamiento de resultados, cuya previsión, prevención y evitabilidad resulta posible, sin interferencias que rompan 
de septiembre de 1990 que como la gran mayoría de la imprudencia estimada en este tema por los tribunales, aprecia imprudencia simple con Infracción de Reglamentos por el proceder negligente del jefe de la empresa al ordenar a sus empleados una misión con total falta de medidas protectoras en concreto, con infracción de la Ordenanza General de Seguridad en el Trabajo de 9 de marzo de 1971 que hasta la aparición de nuestra actual Ley 31/95, constituyó el referente más completo en materia de seguridad e higiene en el trabajo ${ }^{92}$.

Pues bien, estas carencias de este artículo 348 bis a) del Código Penal de 1983 , son básicas para entender la necesidad de los artículos 316,317 y 318 de nuestro actual Código Penal y que vamos a resumir a continuación.

\section{II.1. Época actual}

Nuestro Código Penal vigente, publicado por Ley Orgánica 10/95 de 23 de noviembre de 1995 provino del Proyecto de 1994 en su áni-

el nexo causal, o relación causa-efecto entre aquella omisión de condiciones y sus posibles consecuencias lesivas». Y es fácil apreciar cómo, el criterio con el que apreciar el tipo e imprudencia, en base a la respuesta jurisprudencial, nunca va a ser enteramente objetivo, al basarse para su apreciación en argumentos de carácter subjetivo.

92 Sentencia del Tribunal Supremo de 14 de septiembre de 1990 -RJ 1990/7319-, por la que distingue entre imprudencia temeraria, simple antirreglamentaria y meramente simple, atendiendo a la mayor o menor previsibilidad del evento del resultado de la acción y a la diferente repulsa social ante la infracción del deber por la conducta del agente, al argumentar que, "se definen las diversas especies de culpas que, articuladas en varios tipos, representan una escala jerárquica en cuya cúspide estructural, como la más grave de las infracciones, figura la imprudencia temeraria, suponiendo la misma la eliminación de la atención más absoluta, la inadopción de los cuidados más elementales o rudimentarios exigidos por la vida de relación, suficientes para impedir o contener el desencadenamiento de resultados dañosos previsibles, infringiéndose deberes fundamentales que atañen a la convivencia y a principios transidos de alteridad; en tanto que en la imprudencia simple se acusa la omisión de la atención normal o debida en relación con los factores circunstanciales de todo orden que definen y contornean el supuesto concreto, representando la infracción de un deber de cuidado de pequeño alcance, aproximándose, sin alcanzarla, a la cota exigida habitualmente en la vida social. Debiendo proceder el órgano judicial, en delicada labor valorativa ex post facto, al cuidadoso análisis de los básicos elementos constitutivos de la culpa penal, a la mayor o menor gravedad del fallo psicológico padecido, a la cualidad e intensidad de la desatención, en función del riesgo desencadenado con la torpe actuación; asimismo a la entidad del deber objetivo de cuidado omitido, medida determinada en atención a las generales circunstancias cognoscibles por el ciudadano medio y por el infractor en concreto y a las reglas experienciales o reglamentadas que marcan la pauta de procedencia en el obrar del sujeto, saberes ontológico y gnoseológico cuya referencia es precisa para el adecuado juicio de culpabilidad. La imprudencia simple con infracción de reglamentos surge cuando, a aquella leve negligencia, viene a adicionarse la inobservancia de un precepto de tal indole que normativiza pormenorizadamente la conducta humana en determinado sector de actividad». 
mo de realizar una adaptación positiva a las necesidades sociales más actuales permitiendo la intervención penal si estas necesidades y el ejercicio de los derechos más fundamentales así lo precisaran, de forma que se refunde en el Título XV otros preceptos cuyo objeto era la protección del trabajador: el ya mencionado artículo 499 bis dedicado a los Delitos contra la Libertad y Seguridad en el Trabajo; el 177 bis que penalizaba la limitación del ejercicio del derecho a la libertad sindical y a la huelga; el 496.2. ${ }^{\circ}$ acerca de las amenazas y coacciones en relación al ejercicio del derecho a la huelga; el artículo 427 que recogía el delito de lesiones laborales; y el recientemente comentado 348 bis.a), precedente inmediato en lo relacionado con la penalización de falta de condiciones de seguridad en el trabajo.

Asimismo, nuestro Código Penal vigente incorporó al Título XV el contenido del artículo 54 de la Ley de Emigración 33/71, de 21 de julio, que ahora conforma el artículo 313; introduce de forma novedosa el párrafo $2{ }^{\circ}$ del artículo 312 en relación con el tráfico de mano de obra ilegal, y el artículo 314 acerca de la discriminación en el trabajo.

Esta unificación en el Título XV de todas las conductas que el legislador entendió atentatorias contra los derechos de los trabajadores, pretendía además superar aquellos defectos que las anteriores fórmulas habían planteado. Y es que, la intención de la Ley Orgánica 10/1995 era entre otras extender la tutela penal a tres grandes grupos de intereses, la protección de las condiciones mínimas de trabajo, la protección penal de las condiciones personales de trabajo -casi inequívocamente referidas a la salud-, del principio de autonomía colectiva y de las reglas de actuación colectiva ${ }^{93}$.

En lo que a nuestro estudio respecta, si comparamos los artículos 316, 317 y 318, con su precedente más inmediato, el artículo 348 bis.a), podemos empezar primeramente comentando que ambos son normas penales en blanco si bien la Ley 31/95 de Prevención de Riesgos Laborales, resulta coetánea a este actual Código, con lo que al aludir el precepto a la infracción de las «normas de prevención de riesgos laborales», se está refiriendo a esta Ley y a su normativa de desarrollo en contra de las normas reglamentarias a las que hacía referencia el artículo 348 bis.a), expresión que como hemos visto, era difusa e indeterminada y dejaba en manos de los Tribunales y de la doctrina, el fijar con mayor rigor esta referencia.

En segundo lugar, en lo que respecta a la determinación del sujeto activo como los «estando legalmente obligados», no ha supuesto

${ }_{93}$ Baylos Grau, A. y Terradillos Basoco, J., Derecho Penal del Trabajo..., cit. pág. 30 . 
el artículo 316 ninguna novedad como tampoco lo ha supuesto en la descripción de la acción punible, básicamente la misma tan solo diferenciada en que la nueva determinación de «no facilitar los medios necesarios para que los trabajadores desempeñen su actividad con las medidas de seguridad e higiene adecuadas» realiza una buena simplificación y resumen de lo que en el 348 bis.a) se describía de forma más injustificadamente compleja y farragosa al fijarse la acción punible en «no exigir, no facilitar o no procurar las condiciones para que los trabajadores desempeñen una actividad con las medidas de seguridad e higiene exigibles».

Ahora bien, sí encontramos una sustancial diferencia en lo referente a que el art. 348 bis.a) exigía que la infracción fuera grave, ocasionando un peligro formulado de manera abstracta, mientras que el 316 determina que, si bien la infracción puede ser de cualquier índole e importancia, su consecuencia, esto es, el peligro ocasionado tiene que ser «grave» para justificar una actuación penal.

De manera, que el no fijar la índole de la infracción y pudiendo ser ésta de carácter leve, grave o muy grave genera un efecto protector para el trabajador, pero no así el hecho de que se requiera que el peligro producido sea grave ya que, vuelve a dejar en manos de los Tribunales qué podemos interpretar como un peligro de esta envergadura.

Además, la actual regulación se caracteriza por una graduación de las penas para darle más predominio a la multa pecuniaria en una política criminal que hoy en día apuesta por la mitigación de las penas privativas de libertad por su dudosa eficacia, ya que ésta ha sido últimamente cuestionada desde diversos colectivos sociales.

Y por último, lo que sí considero muy mejorado en nuestra actual regulación, ha sido la alusión amplia a la «salud», superando la escasa referencia a «la vida o integridad física del trabajador» de la anterior regulación que como vimos, dejaba injustamente fuera la preocupación por la integridad psíquica de la que se ocupa ahora de forma muy concienzuda nuestra referencia extrapenal recurrida por la regulación penal, la vigente Ley de Prevención de Riesgos Laborales y sus disposiciones de desarrollo.

Ha sido pues nuestra actual regulación la que ha consagrado el objeto de tutela en su dimensión individual, poniendo el acento en la preocupación acerca de la salud del trabajador en su sentido más amplio y proteccionista, esto es, en el bienestar tanto físico como psíquico del empleado, donde el legislador se ha esforzado por redactar un articulado orientado al respeto y el cuidado prioritario del 
trabajador, salvándose así ya por fin su valoración instrumental en la producción de la empresa y su permanencia a la sombra de otras prioridades más bien económicas en la misma.

La extensa normativa laboral de referencia consolida también esta perspectiva protectora hacia el trabajador, aunque huelga decir que tal y como por desgracia apuntan las últimas estadísticas, la salud en el trabajo es un concepto que aún requiere de muchos esfuerzos para su consolidación y absoluta garantía. 